\title{
CITANDO MARIO JURUNA: IMAGINÁRIO LINGUÍSTICO E A TRANSFORMAÇÃO DA VOZ INDÍGENA NA IMPRENSA BRASILEIRA*
}

Laura R. Graham

Na década de 1970, um líder xavante do centro-oeste brasileiro, chamado Mario Juruna, foi pioneiro no uso estratégico da cultura indígena para atrair a atenção da grande imprensa do país, usando o status de celebridade e a publicidade obtidos para fazer progredir as reivindicações dos Xavante por terra. Juruna também deu início ao uso de novas tecnologias no âmbito das lutas por direitos dos indígenas. Em 1982, foi eleito para o Congresso, tornando-se o primeiro (e, até o momento, o único) indígena brasileiro a ser eleito para um cargo legislativo federal. Embora Juruna fosse um orador eloquente em seu xavante nativo (da família linguística Jê do centro-oeste brasileiro), seu controle do português, a língua do discurso político nacional, era apenas elementar. O discurso em português de Juruna e, em especial, suas representações na mídia, desempenharam um papel fundamental na percepção do público acerca do líder xavante e em sua carreira política.

Ao mesmo tempo em que Juruna usava com engenhosidade novas tecnologias e a imprensa para chamar a atenção para a luta xavante pela recuperação de terras, a imprensa estava usando Juruna para promover os interesses das elites empresariais de acabar com o governo militar. Quando o líder xavante debutou no cenário nacional com seu truncado português indígena, audaciosamente lançando críticas públicas a funcionários do governo que mentiam sobre a devolução de terras roubadas dos Xavante, a grande mídia impressa de propriedade privada estava sujeita à rigorosa censura. Embora sua voz, como outras da oposição, fosse silenciada pelo medo de represálias violentas (levadas a cabo em alguns casos, como o do jornalista Vladimir Herzog, assassinado em outubro de 1975), a grande imprensa usou Juruna — e em particular suas declarações desafiadoras contra o Estado - para sinalizar ao público em geral a existência da discórdia civil. Em seguida, quando as circunstâncias políticas mudaram e as críticas de Juruna ao governo brasileiro deixaram de promover os interesses da elite, a grande mídia deu um giro de 180 graus em seu 
influente peso representacional, virando do avesso a imagem positiva de Juruna. Essas duas caracterizações divergentes da mídia evocam as imagens opostas da narrativa colonial do bom e do mau selvagem. Em um contexto político, Juruna é um defensor puro e primitivo de virtudes políticas nobres; em outro, é um insolente político bárbaro que deve ser abafado ou silenciado e posto em seu lugar - longe dos holofotes políticos e fora do alcance audível.

Neste artigo, valho-me das ferramentas da antropologia linguística para mostrar como a mídia impressa manipulou caracterizações do linguajar e do discurso de Juruna para mobilizar estas figuras narrativas conflitantes e influenciar as percepções públicas do líder xavante. Por meio de uma análise crítica das formas que usaram (ver Fairclough 1989, 1995a, 1995b; van Dijk 1991, 1993, 1999), eu demonstro como editores preeminentes de notícias transformaram radicalmente suas práticas para representar por escrito o linguajar e o discurso de Juruna como "artefatos textuais" (Silverstein \& Urban 1996). Meu estudo fundamenta-se na análise das representações textuais do discurso citado de Juruna e nas discussões sobre o seu linguajar reunidas em mais de 300 artigos de jornais diários e revistas semanais de notícias de 1973, quando Juruna apareceu pela primeira vez no cenário nacional, no auge da ditadura militar, até 1983, quando passou a exercer o cargo de deputado federal. Eu revelo os mecanismos linguísticos específicos que editores de elite usaram para primeiro valorizar e mais tarde estigmatizar o líder xavante, minando, por fim, tanto a imagem pública de Juruna quanto aquilo que ele defendia politicamente. Mostro que, em um breve período de tempo, diversos jornais altamente influentes de circulação diária e grandes semanários de notícias que publicavam citações do discurso de Juruna em português gramaticalmente correto, até mesmo eloquente, passaram a retratar o líder xavante como alguém que mal conseguia balbuciar uma declaração compreensível neste idioma.

Eu argumento que, uma vez Juruna tendo ingressado na política formal, seus adversários políticos puseram-se a atacar o seu linguajar e o seu discurso, usando representações publicadas como meios básicos para destruir sua carreira política. Povos indígenas são particularmente vulneráveis à manipulação da imagem por causa de sua extrema marginalidade e relativa falta de poder (ver, por exemplo, Conklin \& Graham 1995; Meek 2006); eles são suscetíveis à reinscrição nos profundos sulcos que a narrativa do bom selvagem gravou nos imaginários coloniais (ver Slater 2010). A despeito do sucesso de Juruna, ao se envolver magistralmente na grande imprensa para promover os interesses dos Xavante, ao longo dos anos 1970 ele não estava imune a essa manipulação. Mantendo a aparência neutra do relato de notícias, a mídia jornalística impressa usou as ferramentas da linguagem para construir uma "imagem linguística" (Irvine \& Gal 2000) negativa de Juruna que se provou nociva à sua 
carreira política. Esta imagem linguística negativa corrompeu as percepções públicas positivas acerca do líder xavante, corroeu sua imensa popularidade e estabeleceu as bases de sua ruína política final. As consequências desta campanha da imprensa estenderam-se para muito além da carreira política do líder xavante, posto que a imagem negativa de Juruna terminou por afetar desfavoravelmente outros xavante e - se a eleição para um cargo federal for usada como medida - todos os povos indígenas do Brasil.

O caso Juruna demonstra as formas pelas quais as representações ou as "recontextualizações" (Bauman \& Briggs 1990; Silverstein \& Urban 1996) da linguagem e do discurso na esfera pública afetam o modo como - e mesmo se - as vozes de líderes indígenas e das minorias linguísticas subalternas em geral serão ouvidas nas arenas nacionais e internacionais. Ilustra também os obstáculos quase intransponíveis que ativistas indígenas enfrentam quando ganham acesso ao poder político formalmente constituído. Mais amplamente, o caso Juruna serve como aviso, especialmente para os falantes de línguas minoritárias e variedades subalternas das línguas dominantes, de que os recursos linguísticos são ferramentas poderosas que instituições hegemônicas como a imprensa podem empregar (a despeito das convenções editoriais que prescrevem o uso sistemático da língua culta em publicações) para promover os interesses dominantes e influenciar a opinião pública.

Partes interessadas, sejam elas aliadas ou adversárias daqueles que são citados, podem usar as mensagens implícitas da língua representada para estimular alterações na percepção e mesmo mudar a opinião pública a respeito de assuntos de importância política e social. A prática da textualização em qualquer documento, incluindo jornais e, cada vez mais, a internet, inevitavelmente carrega as marcas ideológicas daqueles que são responsáveis por sua produção. Ela pode ser manejada a favor ou contra políticos e outras figuras públicas, numa variedade de contextos. Citações escritas e impressas veiculam muito mais do que as mensagens de falantes cujas expressões são citadas. A citação e a publicação são atos políticos que estão impregnados de poder. Para analisar a transformação que aconteceu na prática editorial para (re)apresentar o linguajar e o discurso de Mario Juruna, ou mesmo a representação escrita do discurso de qualquer figura pública, será útil examinar como e por que isso acontece.

\section{Citação e publicação}

A citação de um discurso e sua publicação por escrito nunca são práticas diretas, ideologicamente neutras. Ambas envolvem processos complexos e 
acarretam relações de poder e autoridade. Segundo enfatiza Mikhail M. Bakhtin (1981, 1986), o discurso citado conecta dois momentos discursivos, trazendo sinais discursivos de situações anteriores para novos contextos sociais ou, no caso do discurso escrito, textos. A citação envolve extrair ou destacar uma série de palavras de um contexto e encaixá-la em um novo, processos que antropólogos linguísticos chamam de "descontextualização", "textualização" e "recontextualização" (ver, por exemplo, Bauman 2004; Bauman \& Briggs 1990; Silverstein \& Urban 1996). Ao citar — por meio de processos de seleção, destaque e reposicionamento das palavras de outro em um novo contexto ou texto - o autor de um novo texto exerce um poder considerável sobre o discurso alheio (ver, por exemplo, Lutz 1990). As formas pelas quais uma fala citada é recontextualizada - preparada para se encaixar em novos (con)textos - afeta interpretações do falante ou autor original, bem como da mensagem e situação social ou texto originais.

Escrever é também uma forma de recontextualização que transforma falas (tanto ditas quanto não ditas) em textos impressos. Um texto escrito é um produto, resultado de processos de produção carregados de ideologia (Fairclough 1989:24; ver também Haviland 1996; Urban 1996) que se estendem desde o desenvolvimento das ortografias, através de escrita gramatical, padronização e transcrição, até a institucionalização em escolas, editoras, imprensa e outros ambientes que controlam e impõem padrões linguísticos. ${ }^{1}$ Na imprensa - uma das diversas instituições linguísticas hegemônicas que disciplinam a linguagem que circula publicamente e a linguagem do discurso público (Bourdieu 1991; Cameron 1995; Williams 1983; ver também van Dijk 1993, 1999) — editores manipulam rotineiramente o discurso que citam - omitindo "impropriedades" como "ehs", gagueiras e palavras ou frases mal pronunciadas - e também tomam decisões quanto a como publicar declarações fora do registro gramaticalmente correto. Citações indiretas e discurso indireto são convenções que os editores podem adotar, ao citar, para manter longe do noticiário a linguagem que não siga o registro padrão (ver Fenigsen 1999).

Os cânones jornalísticos de relato objetivo que determinam a conversão de falas fora do registro culto em formas padronizadas servem ostensivamente como maneira de evitar a transmissão de um viés antiético por meio da representação linguística (ver Society for Professional Journalists 2009). O uso correto ou padronizado da gramática torna a língua "transparente", conduzindo os leitores a "olhar através" dela (Urban 1991:1), simultaneamente percebendo-a como autorizada, dirigindo com isso sua atenção para a mensagem de um texto. Aderindo às ideologias linguísticas ocidentais, que privilegiam a função denotativa da língua, os padrões jornalísticos promovem 
uma ilusão de objetividade linguística. Ideologias da objetividade linguística ofuscam as maneiras pelas quais editores podem legitimar ou estigmatizar atores sociais cujas declarações citam por escrito (ver Fenigsen 1999; ver também Hill 2008). Antes de passar à mídia brasileira e a um exame de suas representações sobre a linguagem e o discurso de Mario Juruna, eu considero quem Juruna era e o contexto nacional em que ganhou preeminência.

\section{Mario Juruna (1942/3?-2002)}

Mario Juruna, ou Dzururã, como era conhecido em seu idioma nativo, foi um líder xavante da reserva indígena de São Marcos, no estado do Mato Grosso (ver Figuras 1 e 2). ${ }^{2}$ Nascido no início dos anos 1940 numa área conhecida como Parabubure, teve estilo de vida seminômade até completar aproximadamente 16 ou 17 anos. Em 1958, violentos confrontos com colonos e fazendeiros invasores obrigaram o grupo de Juruna a buscar abrigo na Missão Salesiana de São Marcos. Na convivência com os salesianos, Juruna foi apresentado à vida entre os waradzu (não indígenas) e à língua portuguesa (Juruna et al. 1982:212-216; também Garfield 2004).

Entre 1964 e 1969, Juruna viajou pela fronteira central do Brasil trabalhando como roceiro e piloto de barco. Ele visitou numerosos grupos indígenas da região central brasileira e testemunhou em primeira mão a corrupção e a cumplicidade da agência indígena estatal com uma poderosa agroindústria que rapidamente adentrava as terras indígenas. Estas experiências, bem como o seu testemunho da exploração pelos salesianos de seu próprio povo em São Marcos (ver Juruna et al. 1982), estabeleceram os alicerces para o desenvolvimento de uma consciência pan-indígena e de sua crítica em relação ao tratamento dado pelo país aos povos indígenas.

Ao longo de suas viagens, Juruna também praticava suas habilidades com a segunda língua. A aptidão para se comunicar em português era rara entre os Xavante naquela época, e a capacidade linguística de Juruna destacou-o em relação a outros líderes contemporâneos. Juruna era um orador eloquente em sua língua nativa. De fato, suas habilidades como orador articulado e qualificado contaram significativamente para o seu estatuto de líder da comunidade, posto que os Xavante têm em alta conta a capacidade de oratória de um líder (ver Maybury-Lewis 1967:145-146; ver também Graham 1993, 1995). Juruna não era, entretanto, especialmente competente em português, a língua do discurso nacional. Ele falava um português básico, lacônico, não gramatical. Não obstante, foi em geral bem-sucedido em transmitir suas ideias para falantes de português. Seu potencial para falar esta língua, aliado ao seu 
Figura 1 - Mapa do Brasil e área das reservas xavante, cortesia de Owners of the Water

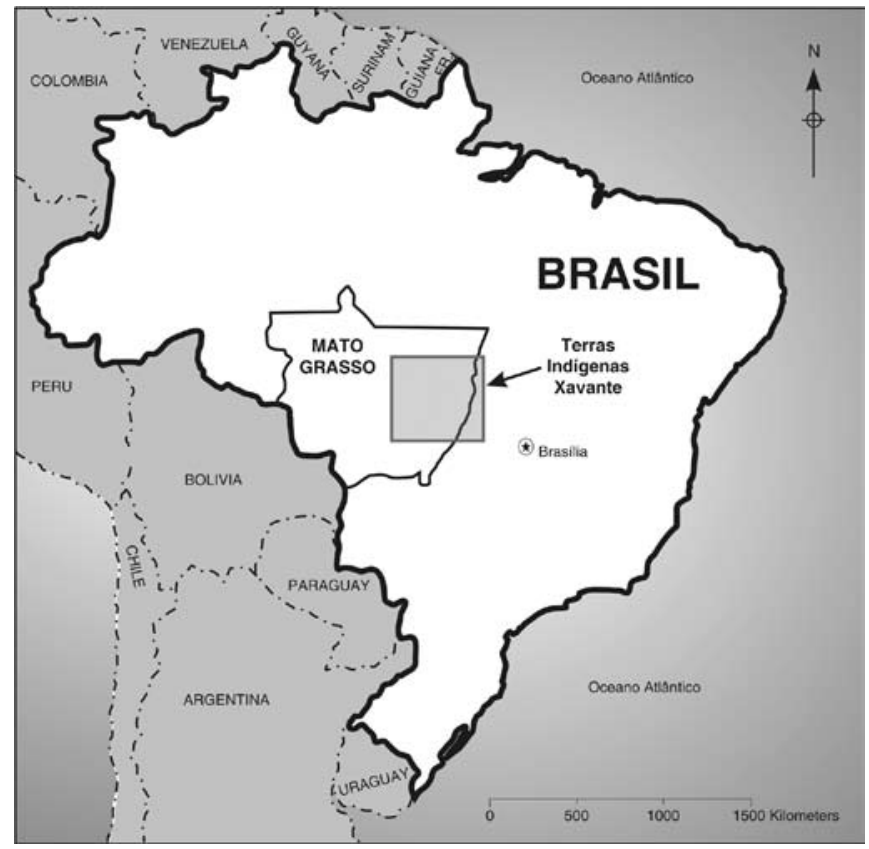

Fonte: Graham et al. 2009.

comportamento intrépido e peremptório fizeram dele um interlocutor eficaz nas relações com representantes da sociedade nacional. ${ }^{3}$

No início dos anos 1970, menos de dez anos depois de os diferentes grupos Xavante serem contatados e estabelecidos perto de postos do governo, ou de missões, ou de postos avançados evangélicos, ${ }^{4}$ Juruna levou a luta dos Xavante pela recuperação de suas terras à capital do país, em um lance sem precedentes na política indígena brasileira. Ele transformou os escritórios da Fundação Nacional do Índio (Funai) e do Ministério do Interior no novo campo de batalha dos Xavante. Enquanto guerreiros tinham brandido clavas de guerra, arcos e flechas para defender suas terras, neste novo teatro militar Juruna encenou confrontos dramáticos com funcionários de alto nível do governo e se envolveu numa feroz guerra de palavras. Ele usou engenhosamente um gravador de fita cassete, bem como um astuto senso do poder da imprensa brasileira, para promover a sua causa. A revista Veja publicou o relato de Juruna sobre sua descoberta do gravador, o aparelho tecnológico que se tornou sua arma característica. De acordo com a Veja, Juruna 
Figura 2 - Área das reservas xavante, cortesia de Owners of the Water

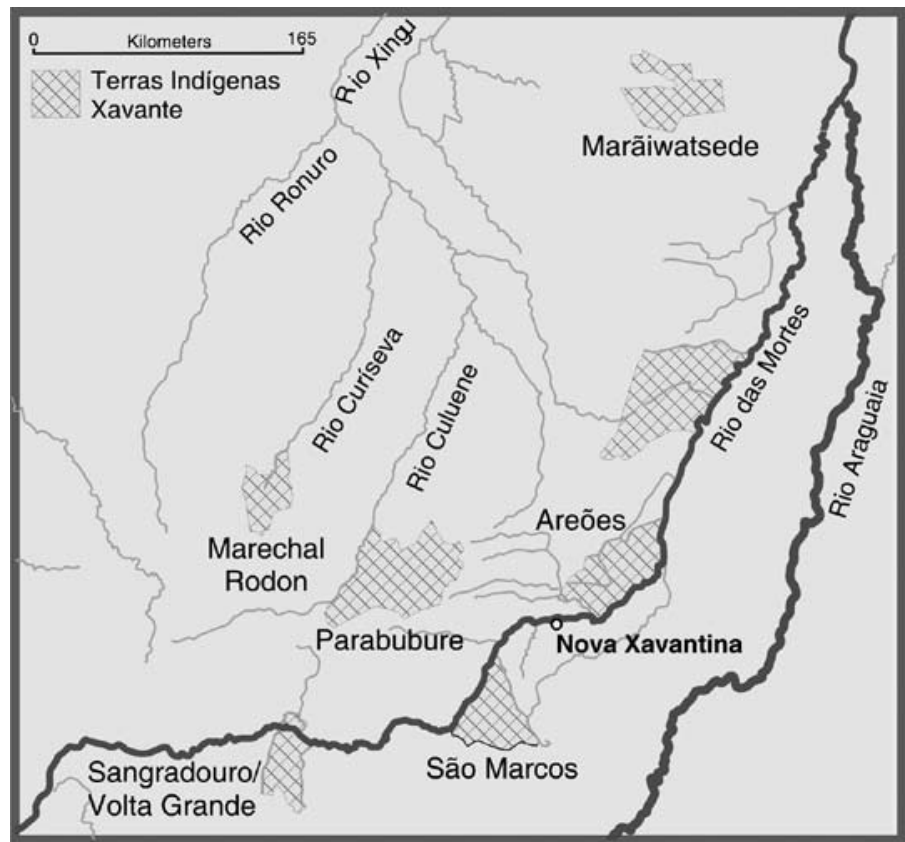

Fonte: Graham et al. 2009.

declarou: "Sempre que eu ia a Brasília para negociar com funcionários do governo não conseguia nada, só promessas. Um dia em Cuiabá, descobri o gravador numa loja e eu vi que ele podia me ajudar" (1980a:33).

Juruna usava o seu gravador Panasonic para gravar funcionários de alto nível fazendo falsas promessas de devolver as terras dos Xavante para o controle do grupo. Mais tarde, diante da imprensa e cercado por dezenas de guerreiros xavante que, adornados com pinturas no corpo e ornamentos de penas, chegavam das comunidades xavante para cantar e dançar em seu apoio, Juruna seria o protagonista de uma encenação espetacular que confrontava promessas e não realizações (ver Figura 3). Ele reproduzia as gravações e expunha publicamente funcionários de alto nível do governo como mentirosos. Notícias desses espetáculos dramáticos e das exposições de Juruna espalhavam-se pelas manchetes de grandes jornais e catapultaram para o centro das atenções do país Juruna e suas reivindicações para que o governo se responsabilizasse por suas promessas (ver Conklin \& Graham 1995; Graham 1995:46-47; Maybury-Lewis 1991; Ramos 1998:105). 


\section{O contexto nacional}

\section{O regime militar brasileiro}

Quando Juruna emergiu para o cenário nacional em meados dos anos 1970, a nação estava dominada por uma ditadura militar repressiva e autoritária (1964-85). ${ }^{5}$ Prisões, torturas, desaparecimentos, censura e decretos arbitrários criavam uma penetrante cultura nacional do medo e silenciavam as vozes de oposição. O Estado governava através da promulgação de "atos institucionais" que davam poderes aos líderes militares para agirem como bem entendessem. Durante o auge da repressão, muitos líderes da oposição, incluindo o político socialista Leonel Brizola (ex-governador do Rio Grande do Sul, que mais tarde se tornaria o principal padrinho político de Juruna) e Luiz Carlos Prestes (líder do Partido Comunista Brasileiro), deixaram o país para viver no exílio.

O Congresso continuou a funcionar, mas foi dominado pelo corrupto partido governista Aliança Renovadora Nacional (ARENA). Foi por duas vezes suspenso e não tinha praticamente nenhum poder (ver Skidmore 1988). O Estado manipulou as eleições por diversos meios, desde o financiamento de campanhas até a fraude cabal, e eliminou todos os partidos políticos, exceto o seu próprio, a ARENA. Em 1979, para criar uma aparência democrática, permitiu a formação de um novo partido, o Movimento Democrático Brasileiro (MDB). Mais tarde, naquele mesmo ano, para quebrar a oposição que se unia e se consolidava em torno do MDB, o Estado permitiu a criação de diversos partidos políticos (ver Skidmore 1989:22-23). Também em 1979, o Congresso aprovou uma Lei da anistia que estimulou o regresso de exilados políticos, incluindo os socialistas Brizola e Prestes, com seus direitos políticos reestabelecidos (ver Skidmore 1989:21). Brizola rapidamente constituiu e liderou o Partido Democrático Trabalhista (PDT), de esquerda e defensor do socialismo, ao qual Juruna mais tarde se afiliou. Esses acontecimentos políticos foram parte de um processo gradual de liberalização, conhecido como abertura, que lentamente moveu a nação rumo à democracia.

Mario Juruna tornou-se uma importante voz de oposição e um ator de peso no processo de abertura. Seus ataques à Funai atingiram o cerne da liderança militar, posto que a Funai, como aponta Alcida Ramos (1998:104), era militar. Era gerida por generais e coronéis do Exército e localizava-se administrativamente no Ministério do Interior, o órgão do governo responsável pelo desenvolvimento dos recursos e das terras da nação. Ao denunciar a Funai e as políticas indigenistas do governo, Juruna condenava todo o regime militar. ${ }^{6}$ 
Figura 3 - Cercado de guerreiros xavante, Juruna reproduz diante da imprensa as gravações em fita de funcionários do governo fazendo falsas promessas

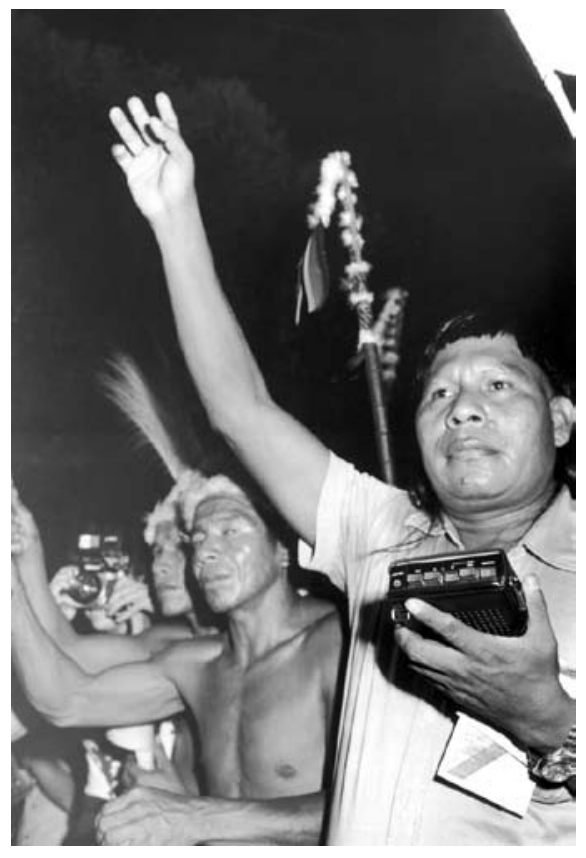

Fotografia: Ricardo Chaves

reproduzida com a permissão de Content xp

\section{Política indígena}

No contexto do regime militar, o controle de povos indígenas e de suas terras era um assunto de alta prioridade na segurança nacional. Embora os povos indígenas representassem apenas uma fração da população nacional e vivessem em áreas que a maior parte dos brasileiros ainda considerava o "interior" (ver Maybury-Lewis 2002), ${ }^{7}$ oficiais militares buscavam controlálos em função de muitos de seus territórios serem ricos em recursos naturais e estarem localizados próximos a fronteiras internacionais desprotegidas. Oficiais militares percebiam áreas indígenas relativamente despovoadas como particularmente vulneráveis à apropriação estrangeira e à infiltração comunista (ver Davis 1977; Garfield 2001:138; Hemming 2003; MayburyLewis 2002; Ramos 1998).

Os militares apresentaram uma série de propostas para ganhar controle sobre os territórios indígenas e privar os povos indígenas de suas proteções legais garantidas pela Constituição, em especial o seu direito a terra. Uma delas foi a "Declaração de Emancipação", em que "emancipação" 
Figura 4 - Juruna com seu passaporte, pronto para embarcar para a Holanda para o IV Tribunal Russell, reunido para julgar crimes contra os povos indígenas das Américas

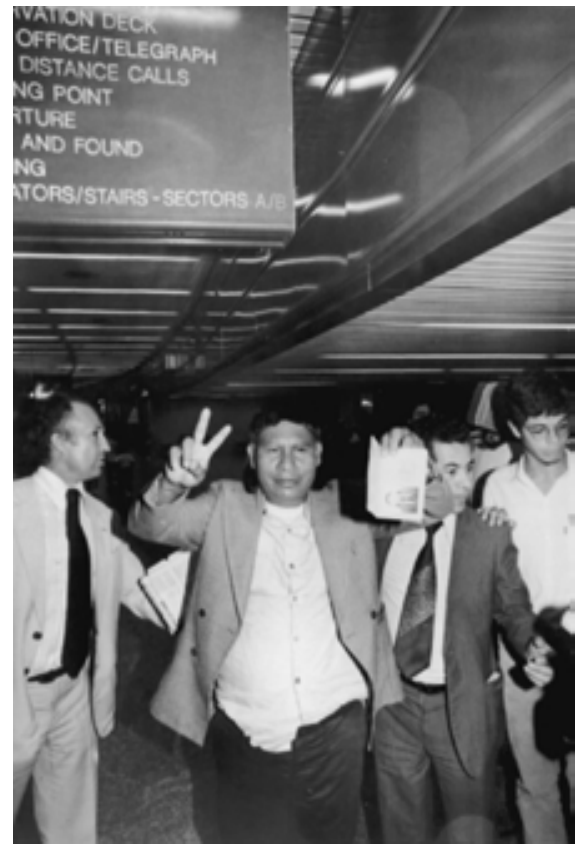

Fotografia: Fernando Pimentel reproduzida com a permissão de Content xp

significava expulsar os povos indígenas de suas terras inalienáveis e colocá-las à venda (Ramos 1998:80, 243-248). Um conjunto de "Critérios para a Identidade Indígena" foi proposto, cuja adoção teria permitido aos oficiais militares determinarem arbitrariamente quem era ou não indígena. E uma reestruturação administrativa conhecida como estadualização teria transferido a supervisão de assuntos indígenas da esfera federal para a esfera estadual, tornando os povos indígenas particularmente vulneráveis a poderosos interesses locais, tais como os de fazendeiros e de empresas mineradoras e madeireiras. ${ }^{8}$

Juruna denunciou essas propostas e se tornou ativo no nascente movimento pan-indígena do país. Ele participou com outros líderes de reuniões patrocinadas por ONGs que se organizavam em torno do direito indígena (ver Hemming 2003:323-351; Maybury-Lewis 2002; Ramos 1988:331-332; Urban 1982). A primeira declaração de oposição de Juruna documentada publicamente data do início da década de 1970, quando ele participou de uma reunião organizada pelo Conselho Indigenista Missionário (CIMI) em Merure, uma comunidade Bororo próxima à Missão de São Marcos, onde ele 
viveu. ${ }^{9}$ Sua declaração — provavelmente publicada em português, a língua franca do movimento indígena nacional - ilustra a atitude desafiadora que lhe rendeu a fama: "[Devemos nos] unir para pressionar ainda mais o governo em Brasília... Porque, se não gritarmos, o governo não vai consertar nada. Devemos gritar na cara [do governo]" (Juruna et al. 1982:189). Ao estender suas críticas ao Estado brasileiro, para além da causa xavante, Juruna desenvolveu críticas mais abrangentes à política indígena do governo, à Funai e ao Ministério do Interior. No fim das contas, suas críticas se dirigiam a todo o sistema de governo brasileiro-waradzu (não indígena).

No final dos anos 1970 e início dos 1980, Juruna ganhou reconhecimento internacional como preeminente porta-voz indígena (ver Conklin \& Graham 1995; Maybury-Lewis 1991; Ramos 1998). Recebeu inúmeros convites para viajar para fora do Brasil a fim de participar de reunióes que estabeleceram as bases para o emergente movimento internacional pelos direitos indígenas (ver Juruna et al. 1982:191-194). ${ }^{10}$ Em 1980, os organizadores do IV Tribunal Russell, um fórum livre internacional de Roterdã, convidaram-no a participar (junto com figuras distintas, como Gabriel García Márquez e Eduardo Galeano) como membro do júri de audiências que convocavam para analisar crimes contra indígenas em toda a América. A ditadura militar brasileira - altamente sensível à sua imagem no exterior e cautelosa em relação às críticas internacionais (ver Conklin \& Graham 1995; Hemming 2003; Ramos 1998:104-114) tentou impedir a participação de Juruna. Recusou a expedição de um passaporte para ele, recorrendo à sua condição, de acordo com o Estatuto do Índio, de menor, tutelado "relativamente incapaz" do Estado (ver Ramos 1998:9498). ${ }^{11}$ A resposta de Juruna, citada na imprensa, explicava de forma diferente a negativa: "A Funai está preocupada que eu diga a verdade sobre a situação indígena brasileira na Holanda" (Veja 1980b:26).

Juruna contestou a decisão que impediu a sua viagem e, auxiliado por uma ONG, entrou com um processo contra o governo. Levou o seu caso ao Supremo Tribunal Federal, onde magistrados debateram os direitos de Juruna, os limites da tutela e as responsabilidades do Estado como guardião de menores indígenas. Retóricas infantilizadoras sobre a indianidade emergiram das discussões dos magistrados do Supremo Tribunal Federal. Numa declaração solidária, o juiz Washington Bolívar de Brito afirmou que "nenhuma nação tem o direito de impedir suas crianças de ir e vir livremente" (83 TFR em 258; ver Ramos 1998:108, grifo meu). A pressão dos organizadores do Tribunal Russell, que nesse ínterim tinham elegido Juruna presidente do júri, foi decisiva nas decisões do Supremo Tribunal (Ramos 1998:107). Juruna ganhou o caso, teve seu passaporte emitido e viajou para a Holanda (Ver Figura 4). 
A imprensa acompanhou de perto o processo de Juruna. Celebrou a resistência do líder xavante e usou o seu caso e as suas críticas verbais à Funai para chamar a atenção para as tentativas do Estado de silenciar as críticas internas. Deu particular atenção à honraria que o júri do tribunal concedeu a Juruna ao elegê-lo presidente. Juruna, extasiado com o apoio da mídia à causa indígena, aparece citado na Veja afirmando que "a imprensa é a maior amiga do índio" (1980a:33). Durante o auge da ditadura militar, a mídia era, de fato, uma boa amiga de Juruna e da causa indígena, já que a grande imprensa usava a voz de Juruna para articular sua condenação ao estado militar.

\section{Juruna, a censura à mídia e o estado militar}

Mario Juruna lançou sua espetacular campanha para recuperar as terras dos Xavante nos corredores dos ministérios federais quando a opressão do Estado estava no ápice. Numa época em que a censura e o medo da repressão silenciavam outras vozes, Juruna irrompia nos gabinetes do governo, apontava funcionários de alto escalão como mentirosos e, com seu gravador e o espetáculo dramático do xavante, deliberadamente expunha as falsas promessas dos funcionários diante da imprensa. Durante a ditadura militar, o Estado de Segurança Nacional controlava o acesso às notícias e à circulação pública de informação por meio de formas diretas e indiretas de censura da imprensa. Uma política de informação repressiva foi criada nos mais altos escalões militares, no Ministério da Justiça, e foi implantada pela Polícia Federal (ver Smith 1997, 2000). O Estado controlava as emissões de rádio e TV por meio das concessões e do franchising e, em menor escala, da programação (Dassin 1982:149). A censura silenciava as vozes de oposição e impedia que a população em geral tomasse conhecimento das críticas ao governo.

De 1968 a 1978, o período mais extremo da intimidação à imprensa pelo governo, o Estado sujeitou diversos veículos da imprensa, incluindo $O$ Estado de São Paulo - OESP (setembro de 1972 — janeiro de 1975) e Veja (1974 — junho de 1976) à rigorosa e burocratizada censura pré-publicação (Smith 1997:82). ${ }^{12}$ Para outros veículos, a ameaça de invasão e ocupação por censores militares, bem como o temor de auditorias e outros meios de intimidação financeira, forçavam a submissão, eufemisticamente conhecida como "autocensura".

Segundo a historiadora Joan Dassin (1982), a censura do Estado à imprensa unificou a categoria jornalística contra os militares, mobilizou a re- 
sistência dos jornalistas e estimulou a "imprensa estabelecida, normalmente conciliatória, a protestar" (Dassin 1982:174). Ao forçar jornalistas e alguns donos de grandes jornais, normalmente membros da elite conservadora estabelecida, a ocuparem posições adversárias, os militares os transformaram em "defensores temporários da liberdade de imprensa" (Dassin 1982:176, grifo meu).

Os editores desenvolveram estratégias inovadoras para chamar a atenção do público para os cortes feitos pelo Estado. Por exemplo, quando o Estado sujeitou o prestigioso e tipicamente conservador OESP à censura prévia, o editor Oliveiros Ferreira inseriu linhas de poemas, receitas culinárias ou imagens de flores onde linhas tinham sido cortadas ou onde teriam sido reproduzidas as principais reportagens jornalísticas censuradas. Ele também escondia conteúdo proibido em lugares inesperados e imprimia metáforas insinuantes em manchetes que leitores esclarecidos entenderiam como críticas (ver Alves 1985:164; Dassin 1982:173; Smith 1997, 2000). As estratégias imaginativas que os editores brasileiros inventaram para subverter a censura foram copiadas pela América Latina afora durante outros regimes militares repressivos dos anos 1970 e 1980 (ver Dassin 1984; ver também Smith 1997).

Para editores de jornal que procuravam formas de alertar os leitores quanto à existência de pontos de vista de oposição, o discurso e a ação de Mario Juruna forneciam um material sensacional e outra forma criativa de os editores subverterem a censura. Juruna era altamente adequado para articular a dissidência: como indígena, era protegido pela sua "inocência", seu status civil de "tutelado relativamente incapaz do Estado". Seu comportamento e suas declarações sensacionais eram bons para a venda de jornais (ver Fonseca $2005,2006)$, e os editores poderiam apostar que o preconceito dos censores contra os povos indígenas os impediria de levar a sério os comentários de Juruna. Além disso, em grande parte devido à atenção internacional atraída, os direitos indígenas eram um dos poucos terrenos em que intelectuais e ativistas sociais podiam defender abertamente os direitos civis (ver Hemming 2003; Maybury-Lewis 2002; Ramos 1998). O direito indígena tornou-se uma questão central em torno da qual múltiplos setores da sociedade civil se combinavam: a grande imprensa, normalmente conservadora, encontrou um terreno comum com a Igreja Católica liberal (Skidmore 1989:11), a Ordem dos Advogados do Brasil (OAB) (Alves 1985) e os intelectuais liberais na defesa dos direitos indígenas. Usando a voz de Juruna, os editores da imprensa puderam expor publicamente a existência da dissidência sem entrarem em conflito com a censura. Os editores inseriam reportagens sobre a extraordinária rebeldia de Juruna em seus jornais e imprimiam suas denúncias, efetivamente usando 
sua voz para empreender seus próprios "atos cotidianos de resistência" (Scott 1990) contra os agentes da censura.

Como xavante, diferentemente de membros de qualquer outro grupo indígena brasileiro, ${ }^{13}$ Juruna era perfeitamente talhado para sinalizar a oposição ao Estado. Os Xavante tinham se tornado famosos por sua feroz resistência à "pacificação" nos anos 1940, quando uma enorme campanha midiática, patrocinada pelo Estado, defendia o controle pelo Estado do "interior" e de seus habitantes como parte de uma agenda patriótica (ver, em especial, Garfield 2001). A campanha da mídia dos anos 1940 romantizava o xavante como o heroico nativo brasileiro icônico. Essa imagem dos Xavante como guerreiros ferozes, bravos e resistentes tornou as implicações indicadoras da selvageria indígena especialmente visíveis para os brasileiros que leram sobre o discurso e as ações desafiadores de Juruna nos anos 1970 e início dos 1980.

\section{Juruna como ventríluco: a amplificação gramatical de sua voz}

Ao citar as declarações de oposição de Juruna no auge da ditadura, os editores as publicavam em português gramaticalmente correto. Eles representavam o seu discurso como "civilizado", efetivamente mascarando as conotações potencialmente negativas de selvageria indígena que poderiam ser transmitidas pela forma linguística (ver Meek 2006). A prática editorial concentrava a atenção nas impactantes mensagens de oposição proferidas por Juruna ao preparar o "cenário" (Jakobson 1960) em torno do conteúdo da mensagem, ao invés de manter as formas não gramaticais de seu discurso real, com isso aumentando as chances de que os leitores compreendessem e respeitassem plenamente a potência de suas mensagens desafiadoras. Por meio destas práticas, os editores promoveram a agenda da elite de expor a oposição à ditadura. Essa propaganda positiva também serviu aos fins de Juruna, já que aumentou a atenção pública à causa xavante. ${ }^{14}$

A voz de Juruna apareceu pela primeira vez na grande imprensa em 1973, em um artigo de Gonzaga Júnior, publicado no Jornal do Brasil (JB), sobre a descoberta, perto de áreas xavante, de um estoque de armas que fazendeiros locais planejavam usar contra os indígenas (ver Juruna et al. 1982:96). O artigo cita os comentários irônicos de Juruna sobre um assunto conexo: um decreto presidencial, recentemente firmado, estabelecendo os limites da Reserva Indígena de Sangradouro (Xavante). Juruna afirmou: "só existe no papel". O depoimento cético de Juruna pode ser lido de duas maneiras. De um lado, articula a perspectiva dos membros de uma cultura oral que questionam a utilidade de um pedaço de papel numa Brasília distante, 
quando estão enfrentando potenciais confrontos com homens armados. De outro, leitores de jornal, membros de um "público branco" (Hill 1999, 2008) de elite, poderiam também interpretar a observação de Juruna como um ataque à credibilidade do Estado militar, que governa promulgando decretos e atos institucionais arbitrários em pedaços de papel em Brasília.

Ao imprimir a observação de Juruna em português gramaticalmente correto, os editores do JB, um jornal diário que era sujeito a restrições indiretas, mas não à censura prévia, lançavam uma sutil, mas aguda, crítica ao Estado. Publicar as palavras condenatórias de Juruna sinalizava a oposição do jornal ao Estado em linguagem propositiva direta, ao invés de por meio das costumeiras metáfora e alusão, táticas que o proprietário, Júlio de Mesquita Neto, e o editor, Oliveiros Ferreira, tinham sido pioneiros em usar para driblar os olhos vigilantes dos censores. Como o JB representava a crítica vinda diretamente da boca de Juruna, a citação funcionava como uma forma de ventriloquismo editorial. Se fosse questionado, o editor poderia se esconder atrás das ideologias linguísticas personalistas do Ocidente e das noções de intencionalidade que associam fortemente declarações a falantes individuais - neste caso, as palavras citadas de um indígena "ingênuo" e "relativamente incapaz" — bem como aos ideais da objetividade jornalística. ${ }^{15}$ Afinal, Juruna fez a crítica; o JB apenas relatou-a.

A partir do início dos anos 1970, quando Juruna debutou na mídia nacional, e até 1981, quando se filiou ao PDT, os editores de jornal estiveram sistematicamente em conformidade com os padrões convencionais da mídia impressa brasileira que determinam que os editores corrijam erros gramaticais. Tal como fariam com qualquer falante, os editores "limpavam" os muitos erros gramaticais no português falado por Juruna; eles apagavam da visão do público leitor as inconsistências gramaticais do seu discurso real. Esta prática dirigia a atenção dos leitores para o conteúdo de suas declarações e também tornava as falas de Juruna mais compreensíveis para leitores de jornal e revista que eram, em grande medida, membros da elite. Por exemplo, numa das primeiras entrevistas publicadas com o líder xavante (20 de novembro de 1974), a Veja cita Juruna afirmando: "Se o Exército tem autoridade eu também tenho autoridade" (Pereira \& Rollemberg 1974:5).

Dado o contexto da ditadura militar no auge da censura e da repressão, esta declaração é verdadeiramente notável. De fato, ter sido dada à Veja, que estava sob censura prévia direta, permissão para publicá-la é extraordinário. Muito provavelmente o preconceito social cegou os censores, fazendo com que deixassem de perceber Juruna como uma ameaça, da mesma forma que atitudes racistas inicialmente impediram que os líderes militares da Funai o levassem - um indígena - a sério quando permitiram que gravasse em fita 
suas conversas. Esta declaração audaciosa ilustra a falta de intimidação de Juruna diante da autoridade do Estado e sinaliza para os leitores a existência de uma voz de oposição destemida.

Cabe observar também que, nesta frase, os editores representam Juruna como alguém que controla as operações fundamentais da gramática — neste caso, as distinções de pessoa e número, bem como a concordância verbal básica. O verbo ter, comumente empregado, aparece conjugado corretamente em duas formas distintas - no presente da terceira pessoa do singular, tem, e no presente da primeira pessoa do singular, tenho. Sublinhei estas formas na citação para que o leitor as perceba com facilidade.

Muitas reportagens jornalísticas durante esse período publicavam citações que representavam Juruna usando formas eloquentes, características do discurso de membros cultos da elite. Um exemplo da edição da Veja mencionada acima retrata o seu discurso cheio de construções e frases gramaticalmente sofisticadas: modo subjuntivo no tempo imperfeito e modo indicativo no tempo condicional (duplamente sublinhados na citação abaixo), bem como concordância relativamente complexa de gênero entre substantivo e pronome ao longo das orações (sublinhado simples abaixo). Estas construções verbais não são características do discurso de pessoas da área rural ou de quem não teve educação formal, sem falar nos povos indígenas recentemente contatados. "À medida que a população indígena fosse aumentando, eu tiraria mais terras para ela" (Pereira \& Rollemberg 1974:5).

Fosse é o modo subjuntivo no tempo imperfeito de ser. Tiraria é o modo indicativo no tempo condicional do verbo tirar. Esta oração também contém concordância relativamente complexa entre substantivo e artigo. A citação, como foi publicada, mostra um uso correto por Juruna da forma feminina do artigo definido a para concordar com o substantivo irregular feminino população da oração precedente. Além disso, a citação demonstra uma concordância correta entre pronomes nas duas orações, numa construção gramatical relativamente complexa. Citações impressas como esta - contendo conjugações verbais complexas, concordâncias corretas modificando o substantivo para substantivos irregulares e concordâncias anafóricas entre orações - representam o discurso em português de Juruna como correto, coerente e até mesmo elegante.

Estas formas elegantes contrastam com o discurso real de Juruna, mesmo mais tarde em sua carreira política. Por exemplo, em um discurso proferido por ele em um comício eleitoral em Cuiabá, em 1984, quando ele já teria mais prática no uso do português, Juruna não emprega nenhuma forma subjuntiva ou condicional. ${ }^{16}$ Além do mais, comete erros em conjugações verbais simples, confundindo pessoas e tempos, como ilustrado pelas frases seguintes: 
Eu quero defender vocês porque eu nasceu pra defender vocês.

Eu não nasceu pra ficar rico nas costas do povo.

(Centro de Documentação, Rede Globo (CEDOC) 1984).

Nestas frases, Juruna usa incorretamente nasceu, a conjugação no passado da terceira pessoa do verbo nascer, em vez do pretérito perfeito na primeira pessoa, nasci.

A aparência das formas, associada ao discurso culto das elites, validou Juruna e sua causa e facilitou a transferência de significados sociais positivos para a sua persona e sua mensagem (ver Fenigsen 1999; Silverstein 1996, 1998). Além disso, a aparência das citações, de eloquência e articulação, sinalizava para os leitores da elite que Juruna - a quem muitos leitores teriam desconsiderado por ser indígena - bem como sua mensagem eram dignos de atenção e respeito. Acima de tudo, essas práticas editoriais centravam a atenção do público na sua provocação em relação ao regime militar.

Embora estas observações gramaticais pareçam triviais, elas são significativas na medida em que, como mostro abaixo, representações publicadas posteriormente pela Veja e por outros jornais diários influentes apresentam Juruna como alguém sem nenhum domínio das funções gramaticais mais elementares (pessoa, número, gênero, concordâncias simples no tempo presente), sem falar no modo subjuntivo e no tempo condicional e nas frases eruditas características do discurso de elite. Até a entrada oficial de Juruna na política partidária, em setembro de 1981, editores de notícias sistematicamente mantiveram convenções editoriais padronizadoras que afastavam da página impressa as inconsistências gramaticais distrativas de seu discurso real.

Estas representações positivas de Juruna e sua posição provocadora na mídia impressa brasileira elevaram o líder indígena à preeminência nacional no final dos anos 1970 e início dos 1980. As declarações de Juruna ressoaram nas frustrações civis e políticas do público em geral - elite e trabalhadores, rurais e urbanos, além de outras minorias - e renderam a ele aclamação nacional como uma das vozes de oposição mais diretas. Enquanto Juruna ganhava o reconhecimento nacional como defensor dos direitos dos indígenas e de outros grupos oprimidos, as elites o celebravam pela sua oposição ao Estado militar. Naquele momento histórico único, o desejo pela mudança política uniu grupos que não se alinhavam tipicamente. Juruna encarnou esta convergência histórica.

Com a aproximação das campanhas para as eleições de novembro de 1982, políticos e partidos da oposição percebiam Juruna — com seu status popular de herói nacional dos direitos civis — como um poderoso aliado de 
relações públicas. Diversos partidos, incluindo o Partido do Movimento Democrático Brasileiro (PMDB), cortejavam-no como potencial candidato para uma vaga no Legislativo. O líder xavante acabou por se alinhar com Brizola e o recém-formado PDT, o único partido político a mencionar negros e povos indígenas na sua plataforma, e Brizola convenceu Juruna a se candidatar a um assento na Câmara dos Deputados junto aos quadros do PDT. Ele fez campanha pela zona sul do Rio de Janeiro, uma região urbana, de classe média, onde o apoio dos trabalhadores a Brizola, que disputava a Prefeitura, e ao PDT era excepcionalmente forte.

Juruna abraçou o programa do PDT e empreendeu campanha vigorosa pelo partido, não apenas no Rio de Janeiro, onde era candidato, mas também por toda a nação. A Folha de São Paulo (FSP) publicou uma citação de um dos discursos de campanha de Juruna que ilustra a postura socialista e inclusiva que lhe rendeu o apoio da classe trabalhadora. Observe-se que esta citação também contém construções relativamente complexas (por exemplo, o futuro do subjuntivo, que sublinho, e o presente do indicativo, duplamente sublinhado) que são característicos do discurso formal, mas não eram típicos do português falado por Juruna.

Se eu for eleito, [...] vou lutar junto com outros pobres que nem os índios, com os pretos, com os favelados, que eu conheço bem porque tenho vivido igual a eles.Vou lutar pelo direito de salário para o trabalhador, pela escritura da terra do índio, que também é filho de Deus (FSP 1982).

\section{Debate e ridicularização na prática da textualização}

Uma vez Juruna tendo ingressado na política formal, seus rivais políticos começaram a perceber o líder xavante como uma ameaça. Deixando de lado a prévia valorização de Juruna como um inocente infantilizado, um homem simples que podia dizer a verdade sem medo porque não reconhecia os constrangimentos sociais de se dizer a verdade (ver A Gazeta 1982), seus opositores passaram a operar com a outra imagem do mito do bom selvagem, ao retratar Juruna como um selvagem beligerante e incontrolável. Ataques contra a sua capacidade de falar português tornaram-se um meio de desacreditá-lo e emudecê-lo (ver Arndt 2010), e também sua mensagem democrática e, por associação, o PDT. Em outubro de 1982, com a aproximação das eleições, a Veja - um veículo de notícias que tinha anteriormente favorecido Juruna com uma cobertura positiva, mas que se voltou contra ele quando se aliou à esquerda - apontou as "dificuldades de comunicação" do líder 
xavante numa reportagem sobre a sua campanha: "O cacique discursou em seu xavanguês habitual, uma mistura de xavante com português que mais da metade da plateia de 1.500 pessoas não entendeu" (1982:26).

O artigo relatava que Brizola veio em seu auxílio declarando que "Juruna irá para o Congresso Nacional, onde falará sua própria língua, o xavante. E os congressistas vão ter que colocar pequenos fones nos ouvidos para ouvir a tradução simultânea" (Veja 1982:26). Afirmando o seu direito de falar em xavante, uma língua indígena brasileira e não uma língua estrangeira, Juruna asseverou: "se os brancos podem aprender a falar o francês e o inglês, por que não o xavante, que é uma língua desta nação?" (O Liberal 1982).

Juruna ganhou as eleições de novembro de 1982 com 31.904 votos. Foram eleições significativas porque, pela primeira vez desde 1965, os eleitores tiveram a oportunidade de votar em candidatos de todos os níveis, exceto para presidente, e os resultados expressaram em grandes números a oposição ao regime militar. Como o maior crítico aberto do tratamento dado pelo Brasil aos povos indígenas que, em grande medida, graças à sua caracterização na imprensa, também representava os interesses dos trabalhadores pobres e de outras minorias oprimidas, Juruna tinha passado a simbolizar a mudança política, bem como a reforma e a justiça social; ele simbolizava uma mudança radical em relação ao status quo. ${ }^{17}$

Depois da eleição, Juruna reforçou a proposta de dirigir-se ao corpo legislativo na sua língua nativa, o xavante. Isto provocou uma enorme discussão no Congresso, que se recusou a permitir o uso de um idioma indígena no âmbito de um órgão oficial do governo e deixou claro que, se Juruna escolhesse falar o xavante, ninguém escutaria o que diria. Nenhum esforço seria feito para providenciar a tradução. Como a falta de tradução era uma forma efetiva de silenciar subalternos que não dominam línguas majoritárias e como a língua xavante não tinha nenhum valor positivo simbólico naquele contexto (ver Graham 2002), para se fazer ouvir, a única opção de Juruna era falar português tão bem quanto fosse possível.

Se a população em geral — elite, classe trabalhadora ou rural — não tinha ainda ouvido o discurso real em português de Juruna antes de sua filiação ao PDT (o que fora possível em função da censura prévia ao rádio e à televisão), depois de sua adesão à campanha foram inúmeras as oportunidades de escutar o líder xavante. O PDT tornou a voz e a mensagem democrática de Juruna preeminentes na sua campanha nacional. Em diversos comícios do PDT, Juruna dirigiu-se pessoalmente a milhares de fãs entusiasmados por todo o país, e muitos de seus discursos, em parte ou integralmente, foram transmitidos em emissões de rádio ou TV. Àquela altura, restrições menos rígidas à mídia eletrônica permitiram que todos os partidos políticos (não apenas o 
governista, a ARENA, como antes) fizessem uso extensivo do rádio e da televisão em suas campanhas (ver Guimarães \& Amaral 1988). Essas emissoras não alteraram ou corrigiram o discurso de Juruna como editores dos meios impressos antes haviam feito. A voz de Juruna, assim como seu português pouco fluente estavam claramente audíveis para o público ouvinte. ${ }^{18}$ Apesar de seu discurso anormal, que muitos residentes urbanos de classe média consideraram engraçado, a mensagem de justiça social de Juruna conquistou a classe trabalhadora, os negros e outros grupos oprimidos. Seu discurso real sinalizava que Juruna não era membro da elite e indicava que ele falava como um representante das - e para as - massas.

Juruna, como concorrente a um assento no Congresso Nacional pelo partido de trabalhadores de esquerda, representava uma real ameaça à oposição da elite. Continuou a emitir declarações públicas apontando sua crença em uma transformação social e política radical. Por exemplo, em novembro de 1982, Juruna é citado na afirmação: "na minha opinião, o Brasil precisa de uma reforma radical" (Folha Metropolitana 1982; O Liberal 1982). Em retaliação, a elite atacou o linguajar e o discurso de Juruna. Editores influentes da imprensa ridicularizaram o seu discurso, descrevendo-o com termos e expressões difamatórios, e também transformaram suas representações impressas para minar sua credibilidade. A começar pela campanha eleitoral e, continuando posteriormente, as representações jornalísticas do discurso citado de Juruna na grande imprensa deixaram de ser sistematicamente adequadas ao padrão formal do português.

Caracterizações satíricas do discurso citado de Juruna apareceram primeiro em charges políticas, uma forma de troça e ridicularização pública à qual político nenhum escapa. As charges são uma forma jornalística pela qual a paródia - em outros contextos, intolerável — é sancionada (ver Fenigsen 1999). No jornalismo impresso brasileiro, as representações satíricas de variações fora da norma culta da língua portuguesa podem acontecer de forma aceitável em charges; variações regionais, por exemplo, são especialmente sujeitas à paródia nas charges brasileiras. ${ }^{19}$ No caso de Juruna, as formas do português fora da norma-padrão serviram, assim como o aspecto do idioma crioulo falado na ilha de Barbados das charges políticas discutidas por Janina Fenigsen, como "intensificador[as] do aspecto satírico das charges, engraçadas justamente em função de [sua] impropriedade" (1999:76). As mensagens de racismo dissimulado que são muitas vezes embutidas discursivamente em charges e em outros espaços públicos de elite ou brancos (Hill 1999) — como filmes, literatura e reportagens jornalísticas — transmitem poderosas mensagens discriminatórias que criam e apoiam divisões sociais e ideologias de preconceito racial e étnico. ${ }^{20}$ 
Figura 5 - Caricatura de Fausto Bergocce: Juruna e seus adversários políticos, Jânio Quadros e Paulo Maluf

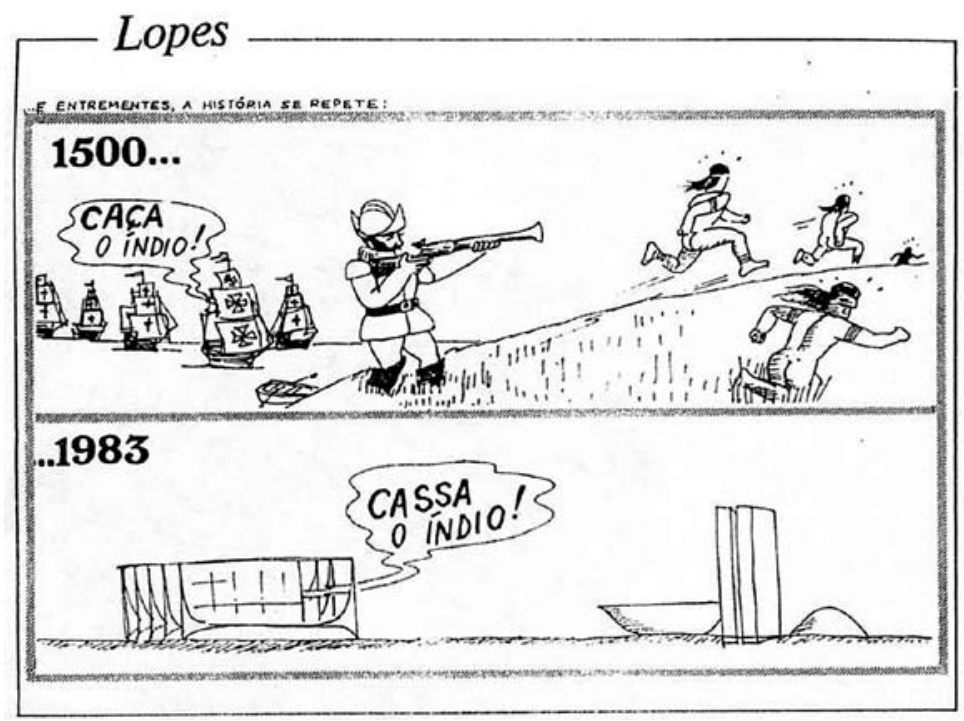

Cortesia de Fausto Bergocce

Algumas charges políticas representavam o discurso de Juruna de maneiras flagrantemente depreciativas, usando formas que ele certamente não empregava. ${ }^{21} \mathrm{Um}$ exemplo mostra Juruna (vestido de terno e gravata, mas com seu penteado xavante característico) dançando em volta de um caldeirão com água fervente cheio de adversários políticos seus (Bergocce 1984; ver Figura 5). O texto apresenta Juruna balbuciando "uuu uuuu", enquanto bate com uma das mãos sobre a boca. Apontando para o canibalismo violento, linguagem "primitiva" e representações de indígenas de Hollywood, incluindo o humilhante Inglês Indígena Hollywoodiano (Hollywood Indian English - HIE) descrito por Barbara Meek (2006), a cena registra Juruna totalmente como "outro" e selvagem. Com seu discurso reduzido a grunhidos, Juruna encarna o bom selvagem, que é incapaz de estruturar um discurso ("civilizado") e é, portanto, efetivamente silenciado. Embora uma análise das representações satíricas de Juruna e de seu discurso em charges políticas esteja além do escopo desta discussão (ver Graham 2008a), levanto aqui a questão para destacar que Juruna e seu discurso forneceram material especialmente rico para tal sarcasmo, que abriu o caminho para representações pejorativas de seu discurso no jornalismo impresso sério. 
Com os retratos depreciativos de seu discurso que apareciam nas charges, imagens de mesmo teor também passaram a se esgueirar pelas reportagens jornalísticas sérias. Veículos influentes de notícias - incluindo Veja, FSP e $\mathrm{CB}^{22}$ — subsequentemente afrouxaram sua adesão aos padrões jornalísticos ao textualizarem o discurso de Juruna. Representações não gramaticais de seu discurso anormal em português começaram a aparecer com frequência em matérias jornalísticas sérias. Publicar citações não gramaticais em reportagens sérias chamou a atenção para o português pouco fluente de Juruna e destacou a disjunção entre seu discurso citado e o discurso padrão de seu entorno textual. Mesmo se as citações publicadas não replicassem com precisão as reais declarações de Juruna (e não há maneira de saber exatamente o que Juruna disse), a publicação de citações diretas exagerava essa "lacuna intertextual" (Briggs \& Bauman 1992), fazendo com que o discurso de Juruna sobressaísse como incongruente e atípico.

Um artigo da FSP de 20 de abril de 1982 chegou a ornamentar a citação direta das declarações de Juruna com anotações editoriais humilhantes.

Brasil é do índio e também de vocês, pobres...

a Tribunal (a Justiça) é nosso, é do preto também.

Eu vou lutar aqui... Se nós todos não gritar (sic), o Diabo toma conta do país.

Muito embora os acréscimos editoriais que aparecem nesta citação possam levar a crer que a intenção tenha sido iluminar — ou "decodificar" — as declarações fora de padrão de Juruna para melhorar a compreensão dos leitores, seu efeito é voltar a atenção dos leitores para os erros do português falado de Juruna, especialmente quando essa citação é contraposta ao pano de fundo anterior da prática invisível e sistemática dos editores de padronizar o discurso citado de Juruna. Aqui, os editores da FSP tornam suas intervenções claramente visíveis; destacam o uso de formas não gramaticais por Juruna e seu emprego equivocado de certos itens lexicais. Por exemplo, o editor chama a atenção para o mau uso por Juruna da palavra tribunal: o texto publicado usa parênteses para mostrar o que o editor entende ter sido o significado desejado por Juruna (a Justiça, o Poder Judiciário). Esta intervenção direciona a atenção do leitor para o engano de Juruna. Da forma como está publicado, o texto citado também enfatiza erros em funções gramaticais básicas; retrata Juruna cometendo diversos equívocos em concordância de gênero (entre o substantivo masculino Tribunal e o artigo definido a ao invés do correto, o) e igualmente destaca a falta de concordância entre o artigo definido $a$ e o pronome possessivo nosso. ${ }^{23}$ 
Talvez o mais impressionante de toda essa citação publicada seja que os editores da FSP explicitamente chamam a atenção para o discurso "inepto" de Juruna ao publicar "(sic)" perto de um erro gramatical, na terceira linha do texto. Para ser gramaticalmente correto nesse contexto, o verbo (gritar) deveria aparecer na terceira pessoa do plural, gritamos. Em vez de corrigir esse erro (da mesma forma como todos os editores fizeram anteriormente), a citação representa o uso incorreto feito por Juruna do infinitivo gritar. A colocação de "(sic)" nesta citação é gritante para os leitores. Ela aumenta o erro gramatical e coloca a "má" gramática de Juruna em foco.

O significado social da "má" gramática não é teleológico. Em alguns contextos, essa linguagem pode ter conotações positivas ou se revestir de prestígio, como no caso do discurso masculino de classe baixa da cidade de Norwich, na Inglaterra, descrito por Peter Trudgill (1972) ${ }^{24}$ Mas no contexto das reportagens jornalísticas, em que convenções editoriais prescrevem a padronização, formas incorretas e fora do padrão sobressaem. Publicar "(sic)" numa citação, no contexto de uma reportagem jornalística, faz com que o erro gramatical fique ainda mais evidente. Representa um movimento editorial deliberado de chamar a atenção para um engano. No caso de Juruna, o uso de sic sinaliza a sua falta de competência oratória e demarca uma habilidade cognitiva limitada (ver Holland \& Quinn 1987; Irvine \& Gal 2000; Lippi-Green 1997; Meek 2006).

Em 1983, o deputado Juruna provocou outro debate público sobre a língua que por pouco não lhe custou o cargo. Desta vez, Juruna estimulou uma polêmica ao referir-se ao gabinete presidencial como "um bando de ladrões corruptos". De acordo com o CB, Juruna afirmou, "com seu forte sotaque xavante", que "todos ministros é ladrão" (1983). Publicada em português gramaticalmente incorreto e descrita como enunciada em discurso "de forte sotaque", esta denúncia não difere das acusações diretas de corrupção no governo feitas por Juruna nos anos 1970. Naquele momento, este tipo de declaração rendera a ele aclamação nacional e fora amplamente divulgado na grande imprensa - em português correto. Mas com o novo contexto político, com a abertura já encaminhada e Juruna membro do Congresso, suas acusações não encontraram apoio entre os políticos civis da elite, que - agora ocupando cargos para os quais tinham sido eleitos - disputavam o controle do governo com os militares. De forma semelhante, os comentários de Juruna não foram encarados com simpatia pelos proprietários de jornais da grande imprensa. Ao invés disso, sua declaração motivou deliberações de uma Comissão no Congresso sobre se o petulante Juruna deveria ser censurado, como que impondo disciplina a uma criança indígena que se comportou mal, ou se deveria ser tomada a medida drástica de anular o seu mandato no Congresso. 
Figura 6 - Caricatura de Lopes: Caça o índio - Cassa o índio

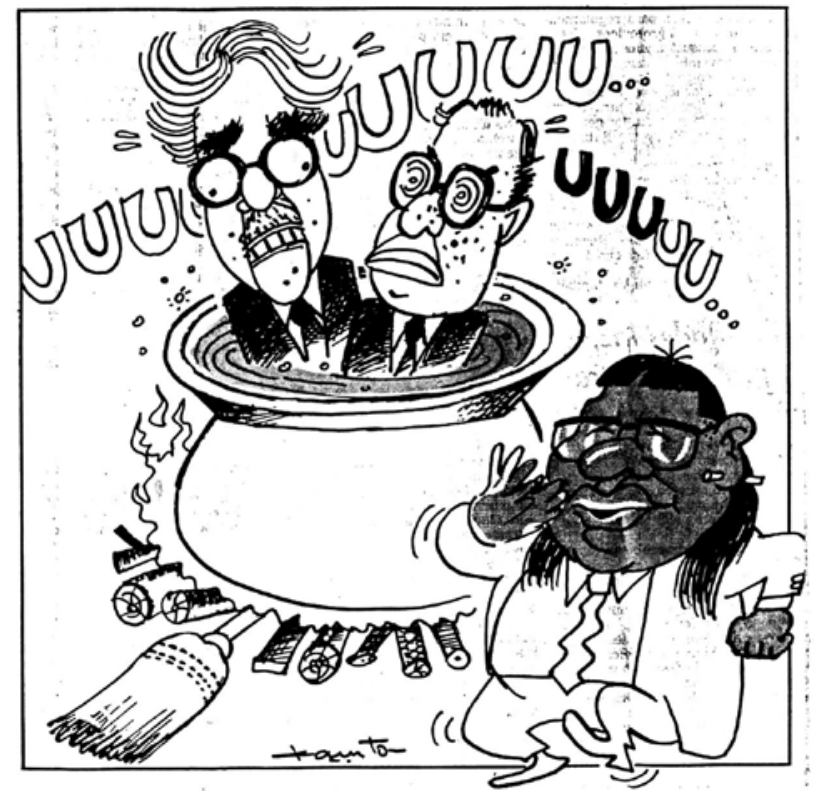

Cortesia de Lopes/CB/DAPress

A discussão sobre a cassação de Juruna esteve centrada na questão da sua intenção. O que o político xavante realmente quis dizer com essa acusação? Referia-se a sua afirmação a membros específicos do gabinete, ao sistema brasileiro-ocidental de governo, ou seria ao tratamento dado pelos europeus e seus descendentes aos povos indígenas ao longo dos últimos 500 anos? A charge na Figura 6 (Lopes 1983) brinca com as palavras homófonas caça e cassa e sintetiza esse debate excepcionalmente bem. O texto diz: "Enquanto isso, a história se repete: 1500 ... caça o índio; 1983... cassa o índio".

A semântica de Juruna foi amplamente debatida na imprensa. Comentários e editoriais sobre o assunto apareceram em todos os grandes jornais. De maneira geral, eram de tom sarcástico e seus autores parodiavam o linguajar de Juruna, fazendo de seu discurso alvo de piadas. Um editorial brincalhão elaborou uma série de diferenças semânticas hipotéticas entre o xavante e o português, provendo uma espécie de glossário xavante para palavras-"chave" em português (Castro 1983). Quando Juruna usava essas palavras, alegava o editorial, o seu significado era diferente dos significados designados a elas por brasileiros não indígenas. Por exemplo, quando Juruna 
dizia "estrangeiro", ele supostamente queria dizer "brasileiro indígena". Além de zombar de Juruna por não falar o português culto, este glossário nivelou sua crítica com a do regime militar, que classificou Juruna como um estrangeiro de fato ao negar-lhe o passaporte para participar do Tribunal Russell na Holanda. Neste novo contexto político, entretanto, era a imprensa e não o aparato do Estado que enfatizava o "estrangeirismo" de Juruna. Os editores usaram a sua incompetência em falar português para enfatizar seu estatuto como Outro (ver Berkhofer 1988:528; também Meek 2006).

Enquanto o Congresso analisava a possibilidade de censurar Juruna ou cancelar o seu mandato, o CB (1983) publicou uma entrevista com ele. Sua representação do discurso citado de Juruna diferia radicalmente da eloquência e do discurso de elite anterior que caracterizara as representações publicadas durante seus primeiros anos como figura pública. Esta recontextualização mostra Juruna enunciando afirmações gramaticalmente incorretas. Nas frases reproduzidas abaixo, Juruna nem sequer conjuga corretamente um dos verbos mais usados do português falado: poder. Ao invés de usar a primeira pessoa eu posso, a citação publicada mostra a declaração de Juruna na terceira pessoa, pode. Além do mais, Juruna comete esse erro repetidamente.

Se eu não pode falar na Câmara, eu pode fazer comício na rua...

Eu não pode voltar mais pra trás.

Correto: Se eu não posso falar na Câmara, eu posso fazer comício na rua... Eu não posso voltar mais atrás (CB 1983).

O texto impresso retrata Juruna como um falante incompetente, já que não consegue estabelecer nem mesmo as construções gramaticais mais básicas ao usar um dos verbos mais comuns na língua falada. Piadas sobre o "mau" português falado por Juruna abundaram na imprensa popular e em outros meios de comunicação de massa. Práticas editoriais que representavam Juruna como um falante incompetente evocavam ideologias discriminatórias que ajudaram a transformar as opiniões populares a respeito do líder xavante.

Cabe ressaltar que nem todos os editores abandonaram os filtros padronizadores prescritos, o que sugere que aqueles que publicaram formas não gramaticais tomaram decisões editoriais conscientes de não "consertar" o discurso de Juruna. Estas representações linguísticas reforçavam enganos políticos que Juruna cometia independentemente. A mais grave das gafes políticas de Juruna aconteceu quando o líder xavante se ofereceu publicamente para devolver um suborno que tinha aceitado de Paulo Maluf, polí- 
tico do PDS. Ao invés de se concentrar na ilegalidade da oferta de Maluf, a imprensa se concentrou na desonestidade de Juruna por ter aceitado o suborno. Em seguida, redobrou o seu assédio a Juruna e apressou a morte política do líder xavante (ver Ramos 1998:105).

Ao enfraquecer a legitimidade de Juruna, a imprensa — representando os interesses da elite empresarial - eliminou um dos mais abertos críticos das relações sociais hegemônicas no Brasil. Nenhuma figura pública destacada protestou em relação às práticas discriminatórias de textualização dos editores. De fato, ideologias referencialistas (Hill 2008), que privilegiam o conteúdo da mensagem e não a forma, impediram grande parte do público leitor de perceber conscientemente esta maneira de discriminação editorial. Pode-se mesmo supor que, como publicar os erros gramaticais fez com que as citações diretas se parecessem mais com o discurso real de Juruna do que as citações eloquentes, a ocorrência desses erros tenha parecido natural para a maioria dos leitores. Esta prática pode até ter sugerido uma objetividade editorial.

Com o aumento do preconceito linguístico contra Juruna, outros meios também sancionaram formas de discriminação linguística. Em seu popular programa de televisão semanal, o comediante Jô Soares fez troça do político xavante, parodiando seu português truncado. Suas piadas caricaturavam a maneira como Juruna falava de um jeito que hoje em dia seria considerado extremamente ofensivo e politicamente incorreto. As imitações de Jô Soares, como as citações gramaticalmente incorretas da imprensa, estimularam as plateias a rir "de" Juruna e de sua maneira de falar, promovendo a ridicularização popular do antes celebrado líder xavante.

\section{Conclusões}

Nas suas caracterizações impressas de Mario Juruna, a mídia jornalística brasileira mobilizou as duas figuras da narrativa infantilizadora colonial e colonizadora do bom selvagem. Celebrou sua inocência política e usou suas críticas ousadas e infantis como escudo para sinalizar a ampla dissensão e criticar o regime militar. De fato, os povos indígenas eram legalmente tutelados pelo Estado. Mas quando Juruna ingressou na cena política formal, não mais se comportava como uma criança inocente. Dessa vez a mídia, ao invés do aparato estatal, assumiu o papel paternal e repreendeu o líder xavante. Efetivamente usou o imaginário linguístico negativo para colocar Juruna em seu devido lugar; "emudeceu-o" ao fazer com que fosse ouvido de forma desprestigiosa (Arndt 2010). 
Em comentário publicado no CB em abril de 1983, o colunista Walter Sotomayor condenava editores pelo padrão discriminatório e desigual demonstrado ao usarem formas não gramaticais em suas citações impressas do discurso de Juruna. Sotomayor tocou no ponto certo com a sua observação: a de que editores corrigiam rotineiramente erros gramaticais quando citavam o discurso de Anthony Motley, o embaixador dos Estados Unidos no Brasil naquele momento, mas que deixavam de fazê-lo no caso de Juruna. Esse tratamento diferenciado, afirmou ele, "revela uma atitude [de respeito para com Motley] que não existe em relação a Juruna" (Sotomayor 1983).

O desrespeito editorial que Sotomayor observou foi comunicado por meio de formas linguísticas e estratégias textuais que iluminei aqui. Vali-me das ferramentas da antropologia linguística e da análise crítica do discurso para revelar os mecanismos precisos que veículos de imprensa autoritários, linguisticamente hegemônicos e influentes usaram para representar o linguajar e o discurso de Juruna, promovendo agendas específicas da elite. A grande imprensa "retocou" a gramática de Juruna e reproduziu suas declarações usando formas eloquentes, associadas à elite educada, para disseminar amplamente as mensagens desafiadoras de Juruna e sinalizar a oposição civil ao comando militar num momento particularmente repressivo do regime militar. Mais tarde, com a abertura política, quando Juruna se tornou uma ameaça real às elites sociais e empresariais e não mais servia à promoção dos interesses dos editores da imprensa, veículos influentes deixaram de lado seus filtros editoriais. De fato, quando deixou de ser útil, deram um giro de 180 graus na prática editorial para representar o linguajar e o discurso de Juruna de forma humilhante. Ao fazê-lo, reproduziram a hierarquia social e colocaram Juruna — o indígena — na posição subordinada à qual, de acordo com o status quo, ele pertencia.

Mario Juruna era sensível à sua vulnerabilidade linguística. Tal como os membros de qualquer grupo que vive a discriminação linguística e os efeitos da hegemonia linguística (ver Urciuoli 1996; Zentella 2003), ele buscou maneiras de reduzir sua predisposição. Ele tentou evitar entrevistas ao vivo com jornalistas que soubesse serem pouco amigáveis (Juruna et al. 1982) e desafiou o Congresso a aceitar sua língua nativa em debates congressistas. Mas a imprensa, que um dia fora - como disse Juruna durante o episódio do Tribunal Russell - "a melhor amiga do índio", voltou-se contra ele. Em 2002, Juruna morreu em um hospital em Brasília de complicações decorrentes de sua longa batalha contra o diabetes. A mídia prestou parca atenção ao seu falecimento, apesar de sua importância como opositor publicamente declarado do Estado militar durante um período crítico na história nacional e apesar da forma como ela tinha repetido suas 
observações para servir aos fins da elite, o que contrasta com as conhecidas acusações de que os indígenas são aqueles que agem como papagaios ao repetirem os comentários de seus aliados mais poderosos (ver, por exemplo, Graham 2002 para uma discussão sobre a crítica de Napoleon Chagnon a Davi Yanomami).

As representações devastadoras feitas pela mídia sobre Juruna tiveram repercussões políticas e consequências para a participação indígena na política nacional. Nas eleições que se seguiram ao seu mandato controverso, muitos líderes indígenas altamente capacitados se candidataram a cargos legislativos, como ele havia previsto. Na esteira da carreira política de Juruna, no entanto, eles enfrentaram estereótipos negativos e estigmas poderosos. Nenhum deles venceu qualquer eleição. Agora, passados mais de 20 anos desde que Juruna completou o seu mandato, muitos líderes indígenas ocupam assentos nos níveis municipal e estadual, mas no decorrer desse tempo nenhum indígena brasileiro conseguiu ser eleito para um cargo legislativo federal. ${ }^{25}$

O caso Juruna ilustra os imensos obstáculos que líderes indígenas, bem como falantes de línguas minoritárias ou de variações linguísticas enfrentam quando tentam obter acesso ao poder político formal. Discurso e linguagem são ferramentas poderosas que podem ser manejadas tanto a favor quanto contra grupos de minorias ou de subalternos para avançar os interesses daqueles que controlam os meios de representação e circulação pública. Aqueles que não dominam as línguas nacionais estão à mercê das instituições hegemônicas (e dos indivíduos) que intermedeiam as representações da língua, seja através da tradução, da transcrição ou de qualquer forma de mediação linguística. A língua e as representações linguísticas são relevantes, como demonstram muitos estudiosos, e isto é especialmente verdadeiro quando os membros de um grupo sujeito à discriminação ingressam na política formal.

Recentemente, no vizinho Peru, de população predominantemente indígena, emergiu o debate público sobre as habilidades literárias da deputada Hilaria Supa, falante de quíchua e espanhol. O jornal diário Correo (23 de abril de 2009), publicou imagens das anotações de Supa, escritas numa variante andina do espanhol e interpretadas como marcadoras de capacidade cognitiva inferior e inabilidade para representar a nação de maneira competente (ver Niño-Murcia 2011). Como Supa é participante da política formal, seu linguajar (por escrito, neste caso) fica sujeito a um escrutínio especial. Esse escrutínio mostra a vitalidade das noções elitistas de linguagem e literalidade, apontando para hierarquias sociais e, ao mesmo tempo, reforçando-as. 
A mídia brasileira evocou de forma semelhante a discriminação linguística para denegrir a imagem de pelo menos um outro líder político além de Juruna, cujas mensagens democráticas e origem social ameaçavam o status quo. Candace Slater (comunicação pessoal 2009), estudiosa de literatura e cultura, lembrou que durante as três campanhas presidenciais malsucedidas de Luiz Inácio Lula da Silva, "ele era frequentemente mencionado em contatos cotidianos, bem como em programas de TV e em diversas peças opinativas da imprensa, como uma espécie de bruto semianalfabeto que não seria capaz de representar o país de maneira competente, articulada e elegante". Um estudo mais sistemático das representações do discurso de Lula durante suas campanhas e sua transformação linguística depois que venceu a eleição de 2002, tornando-se o $35^{\circ}$ presidente do Brasil, resultariam em uma análise fascinante sobre a política linguística. O caso de Lula sugere que qualquer indivíduo cujo perfil social - seja ele étnico, de classe ou de gênero - deixe de se conformar aos padrões da elite estabelecida pode estar sujeito à poderosa discriminação linguística. É por isto que, como James e Leslie Milroy (1999:2) observam, a discriminação linguística é socialmente aceitável enquanto outros meios de expressão de preconceito não o são.

Jornalistas brasileiros contemporâneos que consultei no processo de análise de textos jornalísticos para a presente pesquisa expressaram espanto quando mostrei a eles exemplos da discriminação editorial contra Juruna. Diversos exclamaram: "editores não podem fazer isso!"; muitos afirmaram que o tratamento dado pela mídia impressa a Juruna foi "ultrajante". Claramente, os ajustes editoriais que apontei violaram a ética profissional dos jornalistas e contradizem as celebrações acríticas do papel da imprensa na promoção da democracia durante a ditadura militar; muitos com quem conversei garantiram que tais transgressões jornalísticas não seriam possíveis hoje. Infelizmente, não é este o caso: tenho observado as mesmas táticas que foram empregadas para minar Juruna sendo usadas contra outro líder xavante ousado que está emergindo no cenário nacional, mas este é tema para outro estudo.

Como as ideologias linguísticas privilegiam a atenção ao conteúdo em vez de à forma da mensagem, a manipulação da forma linguística é um meio particularmente poderoso de exercer a discriminação. Embora este tipo de discriminação frequentemente passe despercebido pelas pessoas, seu efeito é poderoso. Atenção à maneira como a mídia e poderosas instituições intermediárias da linguagem exercem essa forma de poder discriminatório pode servir de alerta para estudiosos e ativistas contra futuros abusos e contribuir para entender os mecanismos linguísticos específicos que perpetuam injustiças sociais e maneiras pelas quais a língua pode ser posta a serviço de agendas hegemônicas. 
Membros de grupos dominantes têm manipulado representações do discurso indígena para promover os interesses não indígenas desde que os europeus pisaram pela primeira vez na América. Essas representações, tanto positivas quanto negativas, têm estendido e perpetuado imagens do bom selvagem no século XXI (ver Sorber 1972). O caso Juruna é particularmente expressivo porque as imagens linguísticas que a mídia impressa criou por meio das representações de seu discurso citado mudaram radicalmente em um breve intervalo de tempo. A manipulação do discurso indígena para reproduzir hierarquias sociais não é, entretanto, algo novo. O poder e a autoridade operam na linguagem, muitas vezes, de maneira dissimulada que mascara as formas pelas quais a linguagem pode ser manipulada para promover os interesses de grupos e atores dominantes a serviço da hegemonia e da opressão. A representação do discurso de qualquer pessoa, incluindo o de políticos e figuras públicas, sejam indígenas ou não, pode ser uma arma poderosa nas mãos de partes interessadas. Os povos indígenas, como espero ter demonstrado, são particularmente vulneráveis a esta forma de abuso de autoridade.

Recebido em 19 de dezembro de 2010

Aprovado em 13 de junho de 2011

Tradução de Fernanda Guimarães

Laura R. Graham é professora do Departamento de Antropologia da Universidade de Iowa. E-mail: <laura-graham@uiowa.edu>

\section{Notas}

* A pesquisa para este estudo foi financiada por um Global Scholar Award da Universidade de Iowa; revisei uma versão preliminar deste artigo como pesquisadora residente no Obermann Center for Advanced Study da Universidade de Iowa. A maior parte dos materiais impressos analisados veio dos arquivos do Instituto Socioambiental (ISA), onde Leila Maria Monteiro da Silva proveu assistência inestimável, ajudando-me a localizar os materiais que procurava e, em seguida, auxiliando-me a identificar os detentores dos direitos das charges que reproduzo aqui. Agradeço a 
Fausto Bergocce por autorizar-me pessoalmente a reimprimir a sua charge. Alcida Ramos também ofereceu graciosamente cópias de artigos e charges de seu acervo pessoal. Minha boa amiga Renée Castelo Branco com muitos jeitinhos conseguiu que eu assistisse a materiais sobre os Xavante nos arquivos televisivos particulares da Globo; elas também prestaram muitas formas de apoio a mim e à minha família durante diversas viagens ao Brasil. Sem a sua ajuda, eu não poderia ter concluído esta pesquisa. As jornalistas Renée Castelo Branco, da Globo, Rosa Gauditano e Mônica Telles, da Istoé, e outros colegas da Istoé e do Jornal do Brasil forneceram informações úteis em relação à política editorial na mídia impressa brasileira. Estou em dívida com Maria José Barbosa, Candace Slater e Sylvia Caiuby Novaes por sua revisão cuidadosa da gramática portuguesa nas citações impressas que aparecem neste artigo e, especialmente com Maria José, por suas respostas pacientes a numerosas perguntas. Agradeço a Bruna Franchetto pelo seu apoio e estímulo para publicar este artigo na Mana; aos pareceristas anônimos da Mana; a Sylvia Caiuby Novaes, por seus comentários e sugestões muito proveitosos para tornar este artigo adequado para os leitores brasileiros; e a Fernanda Guimarães, por sua excelente tradução. Agradeço a Bret Gustafson e Judith Maxwell por organizarem a seção intitulada "Movimentos Indígenas e Política Linguística na América Latina: Fala, Representação e Mobilização" (Indigenous Movements and Language Politics in Latin America: Speaking, Representing, and Mobilizing) na Reunião Anual de 1999 da American Anthropological Association, na qual apresentei uma versão bastante preliminar das ideias desenvolvidas aqui; sou grata a Jean Jackson e Bruce Mannheim por seus comentários atentos naquela ocasião. Também ouvi comentários valiosos em discussões que se seguiram às apresentações no Departamento de Estudos Étnicos da Universidade da Califórnia, San Diego, em 2006, e no Grupo de Línguas Indígenas Americanas (Group on American Indigenous Languages) da Universidade da California, Berkeley, em 2009. Em muitos aspectos, estou em dívida com Richard Bauman e agradeço a ele pelo estímulo a pensar criticamente sobre a distorção no discurso citado. Apreciei enormemente os comentários e as sugestões úteis feitos aos esboços anteriores por Grant Arndt, Sylvia Caiuby Novaes, Virginia Dominguez, Francisco Fonseca, Brigittine French, Seth Garfield, Ilana Gershon, Dorothy Hodgson, Mercedes Niño-Murcia, Glenn Penny, Michael Silverstein, Janet Shibamoto Smith e Candace Slater, bem como por Don Donham e os pareceristas anônimos da American Ethnologist e da Mana. Sou também grata a Bruna Franchetto e a Sylvia Caiuby Novaes pelo seu apoio e auxílio nas revisões para publicação pela Mana. Wendy Hunter e Eliza Willis ajudaram a encontrar fontes sobre política brasileira e a imprensa. Jenny White, Jane Hill e T. M. Scruggs merecem especiais agradecimentos pelo seu estímulo, pelas leituras críticas e pelos comentários sobre múltiplos rascunhos anteriores. Conversas com todos esses indivíduos ajudaram enormemente a refinar minhas reflexões e esta argumentação. Quaisquer erros quanto a fatos ou interpretações são, é claro, de minha responsabilidade.

${ }^{1}$ Para discussões sobre os debates ideológicos envolvidos no desenvolvimento de ortografias, ver, por exemplo, Jaffe 1996, Rhydwen 1993 e Schieffelin \& Doucet 1994. Gal \& Irvine 1995, Cameron 1995, Clark \& Ivanič 1997, Irvine \& Gal 2000 e Salomon \& Niño-Murcia (no prelo) discutem as decorrências ideológicas de escrever gramáticas e padronizar linguagens; e Bourdieu 1991; Fairclough 1989, 1995a, 1995b; 
Foucault 1984; Fenigsen 1999; e Hill 2008 iluminam as dimensões ideológicas das instituições linguísticas, como editoras e mídia impressa. Para discussões acerca das formas pelas quais a ideologia afeta a transcrição, ver, por exemplo, Urban 1996, Haviland 1996, Ochs 1979 e Bucholtz 2000.

${ }^{2}$ Os Xavante contemporâneos, que pertencem ao grupo central da família Jê, vivem em 11 reservas indígenas no estado do Mato Grosso, quatro das quais não foram analisadas na Figura 2: Areões I e II, que são contíguas ao território maior de Areões, e Chão Preto e Ubawawẽ, que são contíguas a Parabubure (ver Instituto Socioambiental [ISA] 2010c para divisões legais específicas dentro das áreas xavante). Para uma discussão da organização social xavante e padrões de subsistência tradicional, ver Maybury-Lewis 1967; ver também Lopes da Silva 1986; Graham 1995, 2008b; e Coimbra et al. 2002.

${ }^{3}$ A capacidade de se comunicar na língua dominante nacional é uma habilidade importante para os líderes indígenas nativos da Amazônia de maneira geral (ver, por exemplo, Brown 1993; Graham 2002; Jackson 1991, 1995; Oakdale 2004; Ramos 1988). Hoje, muitos xavante - em especial os homens - falam algum português. Os poucos que falam bem são indivíduos excepcionais que passaram algum tempo vivendo com os brasileiros, geralmente para ir à escola. Os Xavante das comunidades da missão salesiana falam mais português do que aqueles de áreas em que a presença missionária foi menos consistente ou inexistente.

${ }^{4} \mathrm{O}$ período de contato xavante durou aproximadamente 20 anos. Do final dos anos 1940 até 1962, diferentes grupos Xavante estabeleceram relações pacíficas, de variadas maneiras, com representantes da sociedade exterior. Para boas descrições do perfil geral do contato com os Xavante, ver Lopes da Silva 1992; ver também Garfield 2001.

${ }^{5}$ Os militares governaram o Brasil de março de 1964 a janeiro de 1985. Para análises da história política do Brasil durante a ditadura e a transição para a democracia, ver Alves 1985 e Skidmore 1988, 1989.

${ }^{6}$ Curiosamente, trabalhos de cientistas políticos e historiadores sobre o período não mencionam Juruna como um ator importante nesse processo (ver Alves 1985; Skidmore 1989).

${ }^{7}$ Em contraste com alguns países latino-americanos - como a Bolívia, o Peru e a Guatemala - onde povos indígenas são maioria ou perfazem uma grande porcentagem da população, os povos indígenas no Brasil constituem apenas 0,17\% do total (ver Maybury-Lewis 2002:344; ver também ISA 2010c). A maioria da população do país está concentrada em zonas urbanas industrializadas, localizadas ao longo da costa central e sul do Atlântico. Em 1977, o balanço demográfico do país passou de predominantemente rural para urbano (Alisky 1981:91).

${ }^{8}$ Ver Ramos 1998 e também Hemming 2003 para excelentes apreciações destas propostas. 
${ }^{9}$ O CIMI, braço oficial da Conferência Nacional dos Bispos do Brasil (CNBB), instituição liberal, apoiou ativamente a articulação dos líderes indígenas, incluindo Juruna. Patrocinou diversos encontros intertribais, muitos dos quais aconteceram em comunidades indígenas, onde eram menos suscetíveis às tentativas do Estado de bani-los. As tentativas do CIMI de facilitar a organização de líderes indígenas foi análoga ao trabalho feito pelos proponentes da Teologia da Libertação de formar comunidades de base nas populações rurais e pobres (ver Burdick \& Hewitt 2000 para uma boa visão geral e discussão). No Brasil, bem como na América Latina, a Igreja Católica Pós-Vaticano II era com frequência a principal opositora dos regimes governamentais repressivos de direita. A igreja foi uma das poucas instituições que efetivamente se opuseram ao mando militar (Skidmore 1989:11), bem como uma das principais defensoras dos povos indígenas (ver Alves 1985:153-160; Hemming 2003; Juruna et al. 1982; Maybury-Lewis 2002; Ramos 1998).

${ }^{10}$ Ver Niezen 2003 para uma discussão a respeito da emergência do movimento indígena internacional, em particular o envolvimento dos indígenas Cree, da América do Norte.

${ }^{11}$ Antes da Constituição de 1988, que redefiniu o status legal dos indígenas, os povos indígenas eram considerados em condição transitória, que duraria até que eles civicamente "atingissem a maturidade" e fossem "emancipados". A nova Constituição define o status indígena como uma condição permanente e específica de que direitos legais especiais conferidos pela etnicidade não podem ser alienados (ver Ramos 1988:96).

${ }^{12}$ A censura prévia foi amplamente praticada no Brasil de 1969 a 1979, quando o Estado fornecia a todos os veículos de jornalismo listas, chamadas de bilhetinhos, com tópicos proibidos (Smith 1997:120-124). Anne-Marie Smith (1997:82-83) indica que essa censura afetou um pequeno número de publicações amplamente representativas do jornalismo no Brasil: além de OESP e Veja, era direcionada para Opinião e Movimento, dois jornais semanais de oposição política; O Pasquim; O São Paulo, um jornal diocesano; e Tribuna da Imprensa, um diário da cidade (Smith 1997:203, n. 3; ver também Smith 1994:208-227). A censura pós-publicação era ampla; agentes do governo confiscavam edições inteiras ou partes (ou emissões, no caso de mídia eletrônica), fechavam bancas de jornal e, em alguns casos, quando os editores violavam as proibições prévias, fechavam os próprios locais de produção dos materiais (Alves 1985:163-164). Para uma maior discussão sobre a censura à imprensa durante a ditadura militar no Brasil, ver Dassin 1982, 1984; Alves 1985:148; e Smith 1997.

${ }^{13}$ De acordo com o ISA (2010a, 2010b), existem 227 diferentes grupos indígenas no Brasil.

${ }^{14}$ A prática editorial de dar voz a indígenas e suas implicações indexicais são remanescentes do uso que os norte-americanos faziam do imaginário do "índio" selvagem em manifestações de resistência ao domínio britânico, como na Boston Tea Party (ver, por exemplo, Deloria 1998). Sou grata a Jane Hill por ter observado esta comparação. 
${ }^{15}$ Para discussões sobre ideologias linguísticas personalistas ocidentais e noções de intencionalidade, ver Hill 2008; ver também Hill \& Irvine 1993 e Keane 1991.

${ }^{16}$ Sou imensamente grata a Renée Castelo Branco pela inestimável ajuda que permitiu o meu acesso aos arquivos privados da Globo, onde obtive esta gravação do discurso de Juruna.

${ }^{17}$ Alguns brasileiros atribuíram a vitória de Juruna ao cinismo dos eleitores e, de fato, dado o contexto da ditadura militar, os eleitores viram as eleições com considerável desconfiança (ver Skidmore 1988:223). Mas o ceticismo do eleitorado não explica inteiramente a vitória de Juruna nas urnas. Ao votarem em Juruna, os eleitores da classe trabalhadora desencantada da zona sul do Rio escolhiam um homem que se opunha não apenas ao regime militar, mas também a todo o sistema de governo brasileiro ocidental, e isto foi significativo.

${ }^{18}$ Até onde pude observar, as emissoras de televisão não colocavam legendas ao transmitir o discurso de Juruna. Se tivessem escolhido fazê-lo, as legendas teriam o efeito de chamar mais a atenção para o português pouco fluente de Juruna. A incorporação de mensagens veladas em legendas de televisão e cinema é pouco estudada e constitui potencialmente uma área fértil para o entendimento dos mecanismos da discriminação linguística.

${ }^{19} \mathrm{O}$ português do Brasil tem muitas variantes associadas à classe, região, idade e raça; distinções rurais e urbanas também são perceptíveis. Para discussões recentes sobre a variação sociolinguística do português do Brasil, ver, por exemplo, Ilari \& Basso 2006; Peres 2008; Roth-Gordon 2007, 2009; Rubio 2007 e Meira 2007.

${ }^{20}$ Para uma discussão do racismo dissimulado no "espaço público branco", ver Morrison 1992 e Cassuto 1997 sobre as representações de afro-americanos e americanos nativos; Butler 1997 sobre representações de afro-americanos e mulheres; Quiroga 1997; Urciuoli 1996, 2003 e Hill 2008, 1993 sobre a representação de hispânicos; Chun 2004 e Palumbo-Liu 1994 sobre representações de asiático-americanos; e Meek 2006 sobre representações de indígenas americanos nos filmes.

${ }^{21}$ Muitas vezes as charges representavam Juruna usando o pronome pessoal oblíquo tônico mim ao invés de eu (I) na posição de sujeito (ver, por exemplo, Kácio 1984), evocando um padrão que é predominante nas características discursivas associadas estereotipadamente à versão do "índio segundo o homem branco" dos falantes do inglês (ver Berkhofer 1978, 1988; para um aprofundamento sobre as implicações linguísticas deste conceito, ver Meek 2006). O uso do pronome oblíquo mim na posição de sujeito não figura entre os erros gramaticais que os Xavante cometem ao falar português, não obstante suas limitações no domínio da língua. Nunca ouvi um falante de xavante usar inadvertidamente mim em vez de eu. Vale mencionar que é assim que filmes com índios norte-americanos são dublados ou legendados em português: "mim falar", "mim querer" etc. 
${ }^{22}$ Não é possível neste momento identificar afiliações entre partidos ou plataformas políticas específicas e veículos de notícias ou editores. Editores e proprietários da grande mídia mantinham solidariedade geral contra os militares (Francisco Fonseca, comunicação pessoal, fevereiro de 2009).

${ }^{23}$ A citação publicada chama a atenção, portanto, para a concordância equivocada ao mostrar que Juruna acerta uma, mas não as duas formas que devem concordar com o substantivo masculino Tribunal.

${ }^{24}$ Alguns indivíduos que possuem suficiente poder social, econômico ou político podem usar linguagem fora da norma ou incorreta gramaticalmente sem sofrerem grandes consequências. Antes de a Casa Branca tomar medidas para limitar o acesso ao discurso espontâneo de G. W. Bush, a grande mídia preservava o seu "intrigante" uso da gramática inglesa (Silverstein 2003) para fazer o nobre político parecer mais "normal", mais como o cidadão médio dos Estados Unidos. O caso do General Patton é outro exemplo de anglo-americano cuja má gramática pode ter tido um valor positivo. Em outro episódio de representação editorial do discurso indígena norte-americano, em meados do século XX, em Wisconsin, editores de jornais intencionalmente publicavam as falhas gramaticais no inglês do colunista, membro da etnia Ho Chunk, Charles Round Low Cloud, tanto para sinalizar a autenticidade nativa como para debelar ou emudecer suas críticas sociais (Arndt 2010).

${ }^{25}$ O indígena Marcos Terena, do Mato Grosso do Sul, candidatou-se a deputado federal nas eleições de outubro de 2010, mas foi derrotado.

\section{Referências bibliográficas}

A GAZETA. 1982. Juruna. A Gazeta, 25 fev.

ALISKY, Marvin. 1981. Latin american media: guidance and censorship. Ames: Iowa State University.

ALVES, Maria Helena Moreira. 1985. State and opposition in military Brazil. Austin: University of Texas Press.

ARNDT, Grant. 2010. "The making and muting of an indigenous media activist: imagination and ideology in Charles Round Low Cloud's 'indian news'". American Ethnologist, 37(3):499-510.
BAKHTIN, Mikhail M. 1981. "Discourse in the novel". In: M. M. Bakhtin \& Michael Holquist (eds.), The dialogic imagination: four essays. Trad. Caryl Emerson \& Michael Holquist. Austin: University of Texas Press. . 1986. Speech genres and other late essays. Austin: University of Texas Press.

BAUMAN, Richard. 2004. A world of others' words: cross-cultural perspectives on intertextuality. Malden, MA: Blackwell. . \& BRIGGS, Charles. 1990. "Poetics and performance as critical perspectives 
on language and social life". Annual Review of Anthropology, 19:59-88.

BERGOCCE, Fausto. 1984. "Cartoon (Juruna and his political rivals)". Folha de São Paulo, 3 nov.

BERKHOFER, Robert, Jr. 1978. The white man's indian: images of the american indian from Columbus to the present. New York: Knopf. 1988. "White conceptions of indians". In: Wilcomb E. Washburn (ed.), History of indian-white relations. Handbook of north american indians, 4. Washington, DC: Smithsonian Institution. pp. 522-547.

BOURDIEU, Pierre. 1991. Language and symbolic power. John B. Thompson (ed.). Trad. Gino Raymond \& Matthew Adamson. Cambridge, MA: Harvard University Press.

BRIGGS, Charles \& Richard Bauman. 1992. "Genre, intertextuality, and social power". Journal of Linguistic Anthropology, 2(2):131-172.

BROWN, Michael. 1993. "Facing the State, facing the world: Amazonia's native leaders and the new politics of identity". L'Homme, 33(2-4):307-326.

BUCHOLTZ, Mary. 2000. "The politics of transcription". Journal of Pragmatics, 32(10):1439-1465.

BURDICK, John \& Warren Edward Hewitt. 2000. The church at the grassroots in Latin America: perspectives on thirty years of activism. Westport, CT: Praeger.

BUTLER, Judith. 1997. Excitable speech. New York: Routledge.

CAMERON, Deborah. 1995. Verbal hygiene. London: Routledge. . 1998. "Why Is language a feminist issue?". In: D. Cameron (ed.), The feminist critique of language. New York: Routledge. pp. 1-32.

CASSUTO, Leonard. 1997. The inhuman race: the racial grotesque in american literature and culture. New York: Columbia University Press.

CASTRO, Tarso de. 1983. "A língua dos Xavante". Folha de São Paulo, 13 out.

CENTRO DE DOCUMENTACÃO, Rede Globo (CEDOC). 1984. "Mario Juruna Comício Cuiabá, 10 nov". RJ500074049. Globo Archives, Rio de Janeiro.

CHUN, Elaine W. 2004. "Ideologies of legitimate mockery: Margarte Cho's revoicings of mock asian". Pragmatics, 14:263-290.

CLARK, Romy \& IVANIČ, Roz. 1997. The politics of writing. London: Routledge.

COIMBRA, Carlos E. A. Jr.; FLOWERS, Nancy M.; SALZANO, Francisco M. \& SANTOS, Ricardo V. 2002. The Xavante in transition: health, ecology, and bioanthropology in Central Brazil. Ann Arbor: University of Michigan Press.

CONKLIN, Beth \& GRAHAM, Laura R. 1995. "The shifting middle ground: amazonian indians and eco-politics". American Anthropologist, 97(4):695710.

CORREIO BRAZILIENSE (CB). 1983a. "Ninguém vai me censurar". Correio Braziliense, 5 out. . 1983b. "Juruna acusa todo o ministério". Correio Braziliense, 27 set.

DASSIN, Joan. 1982. "Press censorship and the military State in Brazil". In: Jane Leftwich Curry \& Joan R. Dassin (eds.), Press control around the world. New York: Praeger. pp. 149-186. . 1984. "The brazilian press and the politics of abertura". Journal of Interamerican Studies and World Affairs, 26(3):385-414 .

DAVIS, Shelton. 1977. Victims of the miracle: development and the indians of Brazil. Cambridge: Cambridge University Press. 
DELORIA, Philip. 1998. Playing indian. New Haven, CT: Yale University Press.

FAIRCLOUGH, Norman. 1989. Critical discourse analysis: the critical study of language. Harlow, UK: Longman. . 1995a. Language and power. London: Longman. . 1995b. Media discourse. London: Hodder Arnold.

FENIGSEN, Janina. 1999. "'A broke-up mirror': representing Bajan in print". Cultural Anthropology, 14(1):61-87.

FOLHA DE SÃO PAULO (FSP). 1982. "Juruna promete só falar xavante caso seja eleito". Folha de São Paulo, 20 abril.

FOLHA METROPOLITANA. 1982. [title]. Folha Metropolitana, 7 nov.

FONSECA, Francisco C. P. 2005. O consenso forjado: A grande imprensa e a formação da agenda neoliberal no Brasil. São Paulo: Hucitec.

. 2006. "Media and democracy: false convergences". Revista de Sociologia e Política, 1(2):13-24.

FOUCAULT, Michel. 1984. "The order of discourse". In: Language and politics. New York: New York University Press. pp. 108-138.

GAL, Susan \& IRVINE, Judith. 1995. "The boundaries of languages and disciplines: how ideologies construct difference". Social Research, 62(4):967-1001.

GARFIELD, Seth. 2001. Indigenous struggle at the heart of Brazil: State policy, frontier expansion, and the xavante indians, 1937-1988. Durham, NC: Duke University Press.

. 2004. "Mario Juruna: Brazil's first indigenous congressman". In: Peter M. Beattie (ed.), The human tradition in modern Brazil. Wilmington, DE: SR Books. pp. 287-304.

GRAHAM, Laura R. 1993. "A public sphere in Amazonia? The depersonalized collaborative construction of discour- se in Xavante". American Ethnologist, 20(4):717-741.

. 1995. Performing dreams: discourses of immortality among the Xavante of Central Brazil. Austin: University of Texas Press.

. 2002. "How should an indian speak? Brazilian indians and the symbolic politics of language choice in the international public sphere". In: Jean Jackson \& Kay Warren (eds.), Indigenous movements, self-representation, and the State in Latin America. Austin: University of Texas Press. pp. 181-228.

. 2008a. "No laughing matter: racist language in political cartoons of Brazil's Mario Juruna". Paper presented at the 107th Annual Meeting of the American Anthropological Association, San Francisco, 19-23 nov. . 2008b. "Verbete Xavante". Instituto Socioambiental Encyclopedia of Native Brazil. São Paulo: Instituto Socioambiental. Em: https://www.socioambiental.org/pib/epi/xavante/xavante. shtm. Acessado em: 21 jun.

.; PALMAR, David Hernández \& WAIASSÉ, Caimi (dirs.). 2009. Owners of the water: conflict and collaboration over rivers. 34 min. Watertown, MA: Documentary Educational Resources.

GUIMARÃES, Cesar \& AMARAL, Roberto. 1988. "Brazilian television: a rapid conversion to the new order". In: Elizabeth Fox (ed.), Media and politics in Latin America: the struggle for democracy. London: Sage. pp. 125-137.

HAVILAND, John B. 1996. "Text from talk in Tzotzil". In: Michael Silverstein \& Greg Urban (eds.), Natural histories of discourse. Chicago: University of Chicago Press. pp. 45-78.

HEMMING, John. 2003. Die if you must: brazilian indians in the twentieth century. London: Macmillan. 
HILL, Jane H. 1993. "Hasta La vista, baby: anglo spanish in the american southwest". Critique of Anthropology, 13:145-176. . 1999. "Language, race, and white public space". American Anthropologist, 100(3):680-689.

. 2008. The everyday language of white racism. Malden, MA: Wiley-Blackwell. . \& IRVINE, Judith T. (eds.). 1993. Responsibility and evidence in oral discourse. Cambridge: Cambridge University Press.

HOLLAND, Dorothy \& QUINN, Naomi (eds.). 1987. Cultural models in language and thought. Cambridge: Cambridge University Press.

ILARI, Rodolfo \& BASSO, Renato. 2006. O português da gente: a língua que estudamos, a língua que falamos. São Paulo: Contexto.

INSTITUTO SOCIOAMBIENTAL (ISA). 2010a. "Povos indígenas no Brasil, perguntas frequentes". Em: http:// pib.socioambiental.org/pt/c/faq. Acessado em: 4 jan.

. 2010b. "Povos indígenas no Brasil, pesquisa por estado". Em: http://pib. socioambiental.org/caracterizacao. php? $u f=51$. Acessado em: 4 jan.

. 2010c. "Povos indígenas no Brasil, Xavante, introdução". Em: http://pib. socioambiental.org/pt/povo/xavante. Acessado em: 10 abril.

IRVINE, Judith \& GAL, Susan. 2000. "Language ideology and linguistic differentiation". In: Paul V. Kroskrity (ed.), Regimes of language: ideologies, polities, and identities. Santa Fe, NM: School of American Research Press. pp. 35-83.

JACKSON, Jean. 1991. "Being and becoming an indian in the Vaupés". In: Greg Urban \& Joel Sherzer (eds.), Nation-states and indians in Latin America. Austin: University of Texas Press. pp. 131-155.
1995. "Culture, genuine and spurious: the politics of indianness in the Vaupés, Colombia". American Ethnologist, 22(1):3-27.

JAFFE, Alexandra. 1996. "The second annual corsican spelling contest: orthography and ideology". American Ethnologist, 23(4):816-835.

JAKOBSON, Roman. 1960. "Closing statement: linguistics and poetics". In: Thomas Sebeok (ed.), Style in language. Cambridge, MA: MIT Press. pp. 350-377.

JURUNA, Mario; HOHLFELDT, Antonio \& HOFFMAN, Assis. 1982. O gravador do Juruna. Porto Alegre: Mercado Aberto.

KÁCIO. 1984. "Cartoon: Juruna at microphone with Tomahawk, stating, 'Mim, modern Indian...'". Correio Braziliense, 27 jul.

KEANE, Webb. 1991. "Delegated voice: ritual speech, risk, and the making of marriage alliances in Anakalang". American Ethnologist, 18(2):311330.

LIPPI-GREEN, Rosina. 1997. English with an accent: language, ideology and discrimination in the United

States. London: Routledge.

LOPES. 1983. "Cartoon: ... E entrementes, a história se repete". Correio Braziliense, 30 set.

LOPES DA SILVA, Aracy. 1986. Nomes e amigos: da prática xavante a uma reflexão sobre os Jê. São Paulo: Universidade de São Paulo.

. 1992. "Dois séculos e meio de história xavante". In: Manuela Carneiro da Cunha (org.), História dos índios no Brasil. São Paulo: Companhia das Letras / Secretaria Municipal de Cultura. pp. 357-378.

LUTZ, Catherine. 1990. "The erasure of women's writing in sociocultural anthropology". American Ethnologist, 17(4):611-627. 
MAYBURY-LEWIS, David. 1967. Akwẽ, shavante society. Oxford: Clarendon.

. 1991. "Becoming indian in Lowland South America". In: Joel Sherzer \& Greg Urban (eds.), Nation-States and indians in Latin America. Austin: University of Texas Press. pp. 207-235.

2002. "For reasons of State: paradoxes of indigenous policy in Brazil". In: D. Maybury-Lewis (ed.), The politics of ethnicity: indigenous peoples in Latin American States. Cambridge, MA: Harvard University Press. pp. 329-361.

MEEK, Barbara. 2006. "And the injun goes 'how!': representations of american indian english in white public space". Language in Society, 35:93-128.

MEIRA, Vivian. 2007. "The use of the subjunctive in relative clauses and complement clauses in afro-brazilian portuguese". Estudos Linguísticos, 36(2):409-418.

MILROY, James \& MILROY, Leslie. 1999. Authoritarian language: investigating standard english. 3. ed. London: Routlege.

MORRISON, Toni. 1992. Playing in the dark: whiteness and the literary imagination. Cambridge, MA: Harvard University Press.

NIEZEN, Ronald. 2003. The origins of indigenism: human rights and the politics of identity. Berkeley: University of California Press.

NIÑO-MURCIA, Mercedes. 2011. "La buena o mala ortografía como instrumento de jerarquización social". In: M. del C. Lorenzatti (ed.), Procesos de literacidad y acceso a la educación básica de jóvenes y adultos. Córdoba, Argentina: Vaca Narvaja Editor. pp. 54-71.

O LIBERAL. 1982. "Questão indígena, preocupação de Mário Juruna caso eleito". O Liberal, 7 nov., p. 2.
OAKDALE, Suzanne. 2004. "The cultureconscious brazilian indian: representing and reworking indianness in kayabi political discourse". American Ethnologist, 31(1):60-75.

OCHS, Elinor. 1979. "Transcription as theory". In: Elinor Ochs \& Bambi Schieffelin (eds.), Developmental pragmatics. New York: Academic Press. pp. 43-71.

PALUMBO-LIU, David. 1994. "Los Angeles, asians, and perverse ventriloquisms: on the functions of Asian America in the recent american imaginary". Public Culture, 6(2):365-381.

PEREIRA, Alvaro \& ROLLEMBERG, Armando. 1974. "Em busca da sobrevivência, entrevista: Dzururan (Mario), cacique xavante". Veja, pp. 3-6, 20 nov.

PERES, Edenize Ponzo. 2008. "O uso da forma cê em Vitória (ES): uma mudança em curso?". Cadernos Camilliani, 9(2):45-56.

QUIROGA, Jorge. 1997. "Hispanic voices: is the press listening?". In: Clara E. Rodriguez (ed.), Latin looks: images of latinas and latinos in the U.S. media. Boulder, CO: Westview. pp. 36-56.

RAMOS, Alcida. 1988. "Indian voices: contact experienced and expressed". In: Jane Hill (ed.), Rethinking history and myth: indigenous South American perspectives on the past. Urbana: University of Illinois Press. pp. 214-234. . 1998. Indigenism: ethnic politics in Brazil. Madison: University of Wisconsin Press.

RHYDWEN, Mari. 1993. "Kriol: the creation of a written language and a tool of colonization". In: Michael Walsh \& Collin Yallop (eds.), Language and culture in aboriginal Australia. Canberra: Aboriginal Studies Press. pp. 155-168. 
ROTH-GORDON, Jennifer. 2007. "Youth, slang, and pragmatic expressions: examples from brazilian portuguese". Journal of Sociolinguistics, 11(3):322345.

. 2009. "Conversational sampling, race trafficking, and the invocation of the gueto in brazilian hip hop". In: H. Samy Alim, Awad Ibrahim \& Alistair Pennycook (eds.), Global linguistic flows: hip hop cultures, youth identities, and the politics of language. New York: Routledge. pp. 63-77.

RUBIO, Cassio Florencio. 2007. "For a definition of the stigmatized variant in verb agreement in the interior of Sao Paulo state: the scope of the gender/ sex variable". Estudos Linguísticos, 36(2):380-388.

SALOMON, Frank \& NIÑO-MURCIA, Mercedes. No prelo. "The romance of the precise: a peruvian village's life in letters". In: The lettered mountain: a peruvian village's way with writing. Cap. 5. Durham, NC: Duke University Press.

SCHIEFFELIN, Bambi B. \& DOUCET, Rachelle Charlier. 1994. "The 'real' haitian creole: ideology, metalinguistics, and orthographic choice". American Ethnologist, 21(1):176-200.

SCOTT, James. 1990. Domination and the arts of resistance: hidden transcripts. New Haven, CT: Yale University Press.

SILVERSTEIN, Michael. 1996. "Indexical order and the dialectics of sociolinguistic life". In: Risako Ide, Rebecca Parker \& Yukako Sunaoshi (eds.), Proceedings of the Third Annual Symposium about Language and Society, Austin, Texas. Texas Linguistic Forum, 36. Austin: Department of Linguistics, University of Texas. pp. 266-295. . 1998. "The uses and utility of ideology: a commentary". In: Bambi B.
Schieffelin, Kathryn A. Woolard \& Paul V. Kroskrity (eds.), Language ideologies: practice and theory. New York: Oxford University Press. pp. 123-145. . 2003. Talking politics: the substance of style from Abe to "W". Chicago: Prickly Paradigm Press.

. \& URBAN, Greg. 1996. "The natural history of discourse". In: M. Silverstein; G. Urban (eds.), Natural histories of discourse. Chicago: University of Chicago Press. pp. 1-17.

SKIDMORE, Thomas. 1988. The politics of military rule in Brazil, 1964-85. New York: Oxford University Press. . 1989. "Brazil's slow road to democratization, 1974-1984". In: Alfred Stepan (ed.), Democratizing Brazil: problems of transition and consolidation. New York: Oxford University Press. pp. 5-43.

SLATER, Candace. 2010. "Metaphors and myths in news reports of an amazonian 'lost tribe': society, environment, and literary analysis". In: Ismael Vaccaro; Eric Alden Smith \& Shankar Aswani (eds.), Environmental anthropology: methodologies and research design. Cambridge: Cambridge University Press. pp. 157-187.

SMITH, Anne-Marie. 1994. Explaining quiescence: self-censorship in Brazil, 1968-1978. Ph.D. dissertation, Department of Political Science, Massachusetts Institute of Technology. 1997. A forced agreement: press acquiescence to censorship in Brazil. Pittsburgh: University of Pittsburgh Press. . 2000. Um acordo forçado: o consentimento da imprensa à censura no Brasil. Rio de Janeiro: Fundação Getúlio Vargas.

SOCIETY FOR PROFESSIONAL JOURNALISTS. 2009. "Code of Ethics". Em: http://www.spj.org/ethicscode.asp. Acessado em: 21 set. 
SORBER, Edna. 1972. "The noble eloquent savage". Ethnohistory, 19(3): 227-236.

SOTOMAYOR, Walter. 1983. "Chacal: Mário Juruna". Correio Braziliense, 4 out.

TRUDGILL, Peter. 1972. "Sex, covert prestige, and linguistic change in the urban british english of Norwich". Language in Society, 1:179-195.

URCIUOLI, Bonnie. 1996. Exposing prejudice: puerto rican experiences of language, race, and class. Boulder, CO: Westview Press.

.2003. "Containing language difference: advertising in hispanic magazine". In: Richard K. Blot (ed.), Language and social identity. Boulder, $\mathrm{CO}$ : Westview Press. pp. 171-197.

URBAN, Greg. 1982. "Developments in the situation of brazilian tribal populations from 1976-1982". Latin American Research Review, 20(1):7-25. . 1991. A discourse-centered approach to culture. Austin: University of Texas Press.

. 1996. "Entextualization, replication, and power". In: Michael Silverstein \& Greg Urban (eds.), Natural histories of discourse. Chicago: University of Chicago Press. pp. 21-44.

VAN DIJK, Teun. 1991. Racism and the press. London: Routledge. 1993. Elite discourse and racism. Newbury Park, CA: Sage. . 1999. "Discourse and racism". Discourse and Society, 10:147-148.

VEJA. 1980a. "Bye, Bye Holanda". Veja, pp. 32-34, 19 nov. 1980b. "Juruna não voa: Funai proíbe viagem e chefe xavante apela ao STF". Veja, p. 26, 12 nov. 1982. "Leonel Brizola, analista do Rio de Janeiro". Veja, pp. 26-27, 6 out.

WILLIAMS, Raymond. 1983. "Notes on english prose, 1780-1950". In: Writing in society. London: Verso Books. pp. 67-118.
ZENTELLA, Ana Celia. 2003. "'José can you see': latin responses to racist discourse". In: Doris Sommer (ed.), Bilingual aesthetics. New York: Palgrave Press. pp. 51-56. 
Resumo

No presente artigo, revelo os mecanismos textuais que influentes editores de notícias empregaram para manipular a compreensão popular acerca de Mario Juruna, líder xavante que desempenhou um papel importante no avanço da democracia durante a ditadura militar brasileira e se tornou o primeiro indígena eleito para o Congresso Nacional. Argumento que os editores usaram as mensagens implícitas da representação da linguagem para encetar mudanças na percepção do público a respeito do líder xavante, mudando, com isso, a opinião a seu respeito. O caso Juruna evidencia que os recursos linguísticos são ferramentas poderosas que instituições hegemônicas, como a imprensa e outros grupos dominantes, podem empregar para promover seus próprios interesses, influenciando a opinião pública em questões de importância política e social.

Palavras-chave Política linguística, Discriminação linguística, Política de representação, Prática de textualização, Mídia impressa, Indianidade.
Abstract

In this article, I reveal the textual mechanisms that influential news editors employed to manipulate popular understandings of Mario Juruna, a Xavante leader who played an important role in advancing democracy during Brazil's military dictatorship and became the first Indian elected to national office. I argue that editors used the implicit messages of represented language to initiate shifts in the public's perception of the Xavante leader and thereby to change its opinion of him. Juruna's case illustrates that linguistic resources are powerful tools that hegemonic institutions, such as the press, and other dominant parties may employ to advance their own interests and influence public opinion on matters of political and social import.

Key words Language Politics, Linguistic Discrimination, Politics of Representation, Textualizing Practice, Print Media, Indigeneity, Brazil. 